\title{
Challenges and advances in clinical applications of mesenchymal stromal cells
}

\author{
Tian Zhou ${ }^{1,2}$, Zenan Yuan ${ }^{3}$, Jianyu Weng ${ }^{1}$, Duanqing Pei ${ }^{4}$, Xin Du ${ }^{1 *}$, Chang He ${ }^{2^{*}}$ and Peilong Lai ${ }^{1 *}$ (I)
}

\begin{abstract}
Mesenchymal stromal cells (MSCs), also known as mesenchymal stem cells, have been intensely investigated for clinical applications within the last decades. However, the majority of registered clinical trials applying MSC therapy for diverse human diseases have fallen short of expectations, despite the encouraging pre-clinical outcomes in varied animal disease models. This can be attributable to inconsistent criteria for MSCs identity across studies and their inherited heterogeneity. Nowadays, with the emergence of advanced biological techniques and substantial improvements in bio-engineered materials, strategies have been developed to overcome clinical challenges in MSC application. Here in this review, we will discuss the major challenges of MSC therapies in clinical application, the factors impacting the diversity of MSCs, the potential approaches that modify MSC products with the highest therapeutic potential, and finally the usage of MSCs for COVID-19 pandemic disease.
\end{abstract}

Keywords: Mesenchymal stromal cells, Clinical applications, Heterogeneity, Artificial intelligence (Al), Extracellular vesicles, COVID-19

\section{Background}

Mesenchymal stromal cells (MSCs) are pluripotent nonhematopoietic stem cells with self-renewal capability [1] and being intensively investigated in clinical trials. Since the discovery of MSCs from bone marrow by Friedenstein in 1970s, MSCs have been isolated from various sources including muscle, umbilical cord, liver, placenta, skin, amniotic fluid, synovial membrane, and tooth root $[2,3]$, and tested in amounts of preclinical and clinical studies (Fig. 1). It is now understood that MSCs have wide-ranging physiological effects including the maintenance of tissue homeostasis and regeneration $[4,5]$, as well as the immunomodulatory activities suitable for therapeutic application [6]. So their indications have been

\footnotetext{
*Correspondence: miyadu@hotmail.com; hech33@mail.sysu.edu.cn; lai_peilong@163.com

${ }^{1}$ Department of Hematology, Guangdong Provincial People's Hospital, Guangdong Academy of Medical Sciences, Guangzhou 510080, People's Republic of China

2 State Key Laboratory of Ophthalmology, Zhongshan Ophthalmic Center, Sun Yat-Sen University, Guangzhou 510060, People's Republic of China

Full list of author information is available at the end of the article
}

expanded to graft-versus-host disease (GVHD), multiple sclerosis (MS), Crohn's disease (CD), amyotrophic lateral sclerosis (ALS), myocardial infarction (MI), and acute respiratory distress syndrome (ARDS) [7-9].

Over 300 clinical trials of MSC therapies have been completed in patients including but not limited to degenerative or autoimmune diseases (Table 1 lists some of the representative completed studies). Overall, MSCs have exhibited tolerable safety profile and demonstrated promising therapeutic benefits in some clinical settings, which led to regulatory approvals of MSCs in a few countries. In 2011, the Ministry of Food and Drug Safety (Korea FDA) approved Cartistem ${ }^{\circledR}$, a MSC product derived from umbilical cord blood and developed by Medipost for the treatment of traumatic or degenerative osteoarthritis [10]. Thereafter, more MSC products including HeartiCellgram $^{\circledR}$, Mesoblast, TiGenix, and Stempeutics, were approved by regulatory authorities worldwide for the treatment of a variety of diseases. In the USA, Ryoncil (remestemcel-L) is promising to be the first FDAapproved GVHD treatment for children younger than 12, but is still in the stage of safety verification. The amount

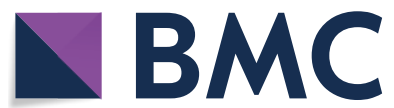

(c) The Author(s) 2021. Open Access This article is licensed under a Creative Commons Attribution 4.0 International License, which permits use, sharing, adaptation, distribution and reproduction in any medium or format, as long as you give appropriate credit to the original author(s) and the source, provide a link to the Creative Commons licence, and indicate if changes were made. The images or other third party material in this article are included in the article's Creative Commons licence, unless indicated otherwise in a credit line to the material. If material is not included in the article's Creative Commons licence and your intended use is not permitted by statutory regulation or exceeds the permitted use, you will need to obtain permission directly from the copyright holder. To view a copy of this licence, visit http://creativecommons.org/licenses/by/4.0/. The Creative Commons Public Domain Dedication waiver (http://creativeco mmons.org/publicdomain/zero/1.0/) applies to the data made available in this article, unless otherwise stated in a credit line to the data. 


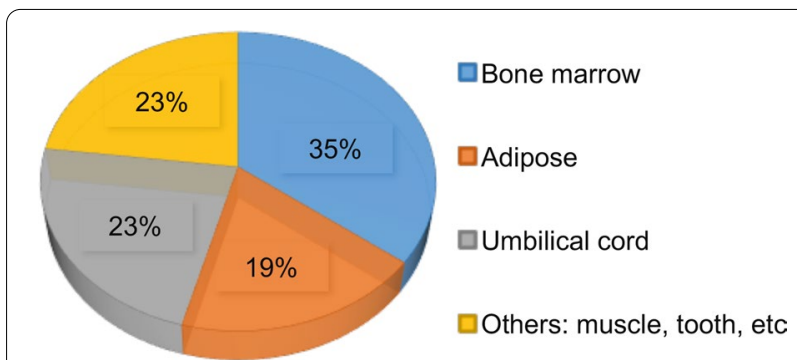

Fig.1 Various sources of MSCs used in the registered clinical trials. MSCs isolated from bone marrow are most widely applied in clinical trials, followed by those from umbilical cord and adipose. MSCs from muscles, tooth are also used

of clinics offering exogenous stem cell therapies has doubled from 2009 to 2014 in the USA. This boom in stem cell clinics with 351 companies putting stem cells for sale in 570 clinics in 2016 indicated the mal-practice of the MSC therapies [11]. Considering the fact that many of the applied exogenous stem cell therapies lack confirmation on safety and effectiveness from large-scale clinical trials and are even illegal, these medical mal-practices do threaten the development of MSC therapies [12].

In this review, we will focus on the major challenges of MSC therapies and the underlying factors leading to the failure of clinical trials. Recent advances and prospects concerning the translation of MSC techniques into clinical practices will also be discussed.

\section{Challenges in technology transfer of MSCs from bench to bedside}

Although transferring MSCs from bench to bedside is theoretically achievable, substantial failures have been reported in many early- or late-stage clinical trials, which account for the disapproval of many products by FDA [13]. Factors contributing to the failure of MSC clinical development include but not limited to the poor-quality control and inconsistent characteristics of MSCs in terms of immunocompatibility, stability, heterogeneity, differentiation, and migratory capacity $[14,15]$ (Fig. 2).

\section{Immunocompatibility of MSCs}

MSCs were immune privileged due to the low expression of MHC-I and HLA-I, and no expression of HLAII or costimulatory factors such as CD40, CD80 and CD86. MSCs can be transplanted as allogeneic cells with a low risk of rejection. Generally, the original MSCs are believed to have low immunogenicity [16]. Most MSC products are manufactured by amplifying a small number of cells obtained from donors, which can increase MSC immunogenicity caused by inappropriate processes and culture conditions. After MSCs infusion, the in vivo inflammatory molecules in turn increase MSC immunogenicity and further decrease MSCs viability and differentiation capacity, particularly when administrating xenogenic MSCs including human MSCs in animal models [17]. Although the primary immunogenicity of MSCs derived from in vitro experiments might be minimal, the secondary immunogenicity induced by in vivo positive feedback loops can cause the absence of efficacy reported in most clinical trials.

Studies have shown that inflammatory molecules (such as interferon- $\gamma$ ), increased cell density, and/or serum deprivation can induce high expression of MHCII in MSCs, while TGF- $\beta$ suppresses MHC-II expression [18]. The immune compatibility between donors and recipients is the key to reduce the risk of rejection in the event of long-term treatments with repeated infusions, in conditions requiring promotion of transplanted bone marrow integration, or post-renal transplantation rejection treatments [19]. It has been reported that repeated intra-articular injection of allogeneic MSCs is more likely to cause an adverse reaction than autologous cells when administered in the same manner [20]. The same observations were reported in horses treated with intracellular xenogen-contaminated autologous MSCs (such as FBS) or non-xenogen-contaminated allogeneic MSCs [21].

MSCs of high quality is the first step to ensure the safety and efficacy in clinical trials. Understanding the molecular and cellular mechanisms underlying the immune incompatibility of MSCs will help to improve the manufacture of MSC products.

\section{Stemness stability and differentiation of MSCs}

MSCs have mesodermal lineage differentiation potential and the potential to regulate tissue regeneration by mediating tissue and organ repair, as well as replacing damaged cells [22]. Different tissue-derived MSCs exhibit tendencies to differentiate into different end-stage lineage cells $[23,24]$, and such regeneration and differentiation contribute to distinctive clinical efficacy.

Several laboratories have analyzed the proteome modifications associated with MSCs differentiation [25, 26]. They indicated that "stemness" genes were highly expressed in undifferentiated and de-differentiated MSCs $[27,28]$. These highly stemness-related gene clusters in MSCs have been found to be mainly involved in the proliferation, differentiation, and migration [29]. When MSCs differentiated into osteoblasts, chondrocytes, and adipocytes, expressions of these genes significantly decreased, underlining their unique characteristics. Table 2 lists typical stemness genes of MSCs.

Serial passaging in long-term culture could negatively affect the expression of stemness genes [48, 49]. A previous study indicated that $\mathrm{CD} 13, \mathrm{CD} 29, \mathrm{CD} 44, \mathrm{CD} 73$, 
Table 1 Some representative registered clinical trials of MSC therapies

\begin{tabular}{|c|c|c|c|}
\hline NCT Number & Title & Phase & Sponsor/Collaborators \\
\hline NCT02097641 & $\begin{array}{l}\text { Human Mesenchymal Stromal Cells For Acute Respiratory Distress } \\
\text { Syndrome (START) }\end{array}$ & Phase 2 & $\begin{array}{l}\text { National Heart, Lung, and Blood Institute (NHLBI) } \\
\text { Massachusetts General Hospital } \\
\text { Stanford University } \\
\text { University of Pittsburgh } \\
\text { University of Minnesota } \\
\text { Ohio State University } \\
\text { University of California, San Francisco }\end{array}$ \\
\hline NCT00957931 & $\begin{array}{l}\text { Allo-HCT MUD for Non-malignant Red Blood Cell (RBC) Disorders: } \\
\text { Sickle Cell, Thal, and DBA: Reduced Intensity Conditioning, Co-tx } \\
\text { MSCs }\end{array}$ & Phase 2 & $\begin{array}{l}\text { Stanford University } \\
\text { University of Minnesota } \\
\text { University of Alabama at Birmingham }\end{array}$ \\
\hline NCT01771913 & $\begin{array}{l}\text { Immunophenotyping of Fresh Stromal Vascular Fraction From } \\
\text { Adipose-Derived Stem Cells (ADSC) Enriched Fat Grafts }\end{array}$ & Phase 2 & University of Sao Paulo \\
\hline NCT01909154 & $\begin{array}{l}\text { Safety Study of Local Administration of Autologous Bone Marrow } \\
\text { Stromal Cells in Chronic Paraplegia (CME-LEM1) }\end{array}$ & Phase 1 & Puerta de Hierro University Hospital \\
\hline NCT03102879 & Encapsulated Mesenchymal Stem Cells for Dental Pulp Regeneration & $\begin{array}{l}\text { Phase } 1 \\
\text { Phase } 2\end{array}$ & $\begin{array}{l}\text { Universidad de los Andes, Chile } \\
\text { Cells for Cells, Chile }\end{array}$ \\
\hline NCT02467387 & $\begin{array}{l}\text { A Study to Assess the Effect of Intravenous Dose of (aMBMC) to } \\
\text { Subjects With Non-ischemic Heart Failure }\end{array}$ & N/A & $\begin{array}{l}\text { CardioCell LLC } \\
\text { Stemedica Cell Technologies, Inc }\end{array}$ \\
\hline NCT02387749 & $\begin{array}{l}\text { Effect Of Mesenchymal Stem Cells Transfusion on the Diabetic Periph- } \\
\text { eral Neuropathy Patients }\end{array}$ & N/A & Cairo University \\
\hline NCT01932164 & $\begin{array}{l}\text { Use of Mesenchymal Stem Cells for Alveolar Bone Tissue Engineering } \\
\text { for Cleft Lip and Palate Patients }\end{array}$ & N/A & Hospital Sirio-Libanes \\
\hline NCT02481440 & Repeated Subarachnoid Administrations of hUC-MSCs in Treating SCI & $\begin{array}{l}\text { Phase } 1 \\
\text { Phase } 2\end{array}$ & Third Affiliated Hospital, Sun Yat-Sen University, China \\
\hline NCT02165904 & $\begin{array}{l}\text { Subarachnoid Administrations of Adults Autologous Mesenchymal } \\
\text { Stromal Cells in SCl }\end{array}$ & Phase 1 & Emory University \\
\hline NCT02330978 & $\begin{array}{l}\text { Intravitreal Mesenchymal Stem Cell Transplantation in Advanced } \\
\text { Glaucoma }\end{array}$ & Phase 1 & University of Sao Paulo \\
\hline $\begin{array}{l}\text { NCT01183728 } \\
\text { NCT01586312 }\end{array}$ & $\begin{array}{l}\text { Treatment of Knee Osteoarthritis With Autologous/ Allogenic Mesen- } \\
\text { chymal Stem Cells }\end{array}$ & $\begin{array}{l}\text { Phase } 1 \\
\text { Phase } 2\end{array}$ & $\begin{array}{l}\text { Red de Terapia Celular } \\
\text { Fundacion Teknon, Centro Medico Teknon, Barcelona } \\
\text { University of Valladolid }\end{array}$ \\
\hline NCT02037204 & $\begin{array}{l}\text { IMPACT: Safety and Feasibility of a Single-stage Procedure for Focal } \\
\text { Cartilage Lesions of the Knee }\end{array}$ & $\begin{array}{l}\text { Phase } 1 \\
\text { Phase } 2\end{array}$ & UMC Utrecht \\
\hline NCT02958267 & $\begin{array}{l}\text { Investigation of Mesenchymal Stem Cell Therapy for the Treatment of } \\
\text { Osteoarthritis of the Knee }\end{array}$ & Phase 2 & OhioHealth \\
\hline NCT00587990 & $\begin{array}{l}\text { Prospective Randomized Study of Mesenchymal Stem Cell Therapy in } \\
\text { Patients Undergoing Cardiac Surgery (PROMETHEUS) }\end{array}$ & $\begin{array}{l}\text { Phase } 1 \\
\text { Phase } 2\end{array}$ & $\begin{array}{l}\text { National Heart, Lung, and Blood Institute (NHLBI) } \\
\text { Johns Hopkins University Specialized Center for Cell Based Therapy } \\
\text { The Emmes Company, LLC } \\
\text { University of Miami }\end{array}$ \\
\hline NCT01385644 & $\begin{array}{l}\text { A Study to Evaluate the Potential Role of Mesenchymal Stem Cells in } \\
\text { the Treatment of Idiopathic Pulmonary Fibrosis }\end{array}$ & Phase 1 & $\begin{array}{l}\text { The Prince Charles Hospital } \\
\text { Mater Medical Research Institute }\end{array}$ \\
\hline NCT02509156 & Stem Cell Injection in Cancer Survivors & Phase 1 & $\begin{array}{l}\text { The University of Texas Health Science Center, Houston } \\
\text { National Heart, Lung, and Blood Institute (NHLBI) }\end{array}$ \\
\hline NCT02379442 & $\begin{array}{l}\text { Early Treatment of Acute Graft Versus Host Disease With Bone Marrow- } \\
\text { Derived Mesenchymal Stem Cells and Corticosteroids }\end{array}$ & $\begin{array}{l}\text { Phase } 1 \\
\text { Phase } 2\end{array}$ & $\begin{array}{l}\text { National Heart, Lung, and Blood Institute (NHLBI) } \\
\text { National Institutes of Health Clinical Center (CC) }\end{array}$ \\
\hline NCT01087996 & $\begin{array}{l}\text { The Percutaneous Stem Cell Injection Delivery Effects on Neomyogen- } \\
\text { esis Pilot Study (The POSEIDON-Pilot Study) }\end{array}$ & $\begin{array}{l}\text { Phase } 1 \\
\text { Phase } 2\end{array}$ & $\begin{array}{l}\text { University of Miami } \\
\text { National Heart, Lung, and Blood Institute (NHLBI) } \\
\text { The Emmes Company, LLC }\end{array}$ \\
\hline NCT02013674 & $\begin{array}{l}\text { The TRansendocardial Stem Cell Injection Delivery Effects on Neomyo- } \\
\text { genesis Study (The TRIDENT Study) }\end{array}$ & Phase 2 & $\begin{array}{l}\text { The Emmes Company, LLC } \\
\text { University of Miami }\end{array}$ \\
\hline NCT01392625 & $\begin{array}{l}\text { PercutaneOus StEm Cell Injection Delivery Effects On Neomyogenesis } \\
\text { in Dilated CardioMyopathy (The POSEIDON-DCM Study) }\end{array}$ & $\begin{array}{l}\text { Phase } 1 \\
\text { Phase } 2\end{array}$ & $\begin{array}{l}\text { National Heart, Lung, and Blood Institute (NHLBI) } \\
\text { University of Miami }\end{array}$ \\
\hline NCT00768066 & $\begin{array}{l}\text { The Transendocardial Autologous Cells (hMSC or hBMC) in Ischemic } \\
\text { Heart Failure Trial (TAC-HFT) }\end{array}$ & $\begin{array}{l}\text { Phase } 1 \\
\text { Phase } 2\end{array}$ & $\begin{array}{l}\text { University of Miami } \\
\text { The Emmes Company, LLC }\end{array}$ \\
\hline NCT00629018 & $\begin{array}{l}\text { Safety and Efficacy Study of Stem Cell Transplantation to Treat Dilated } \\
\text { Cardiomyopathy }\end{array}$ & Phase 2 & $\begin{array}{l}\text { University Medical Centre Ljubljana } \\
\text { Blood Transfusion Centre of Slovenia } \\
\text { Stanford University }\end{array}$ \\
\hline NCT00927784 & $\begin{array}{l}\text { Effect of Intramyocardial Injection of Mesenchymal Precursor Cells on } \\
\text { Heart Function in People Receiving an LVAD }\end{array}$ & Phase 2 & $\begin{array}{l}\text { Icahn School of Medicine at Mount Sinai } \\
\text { National Heart, Lung, and Blood Institute (NHLBI) } \\
\text { Angioblast Systems }\end{array}$ \\
\hline
\end{tabular}




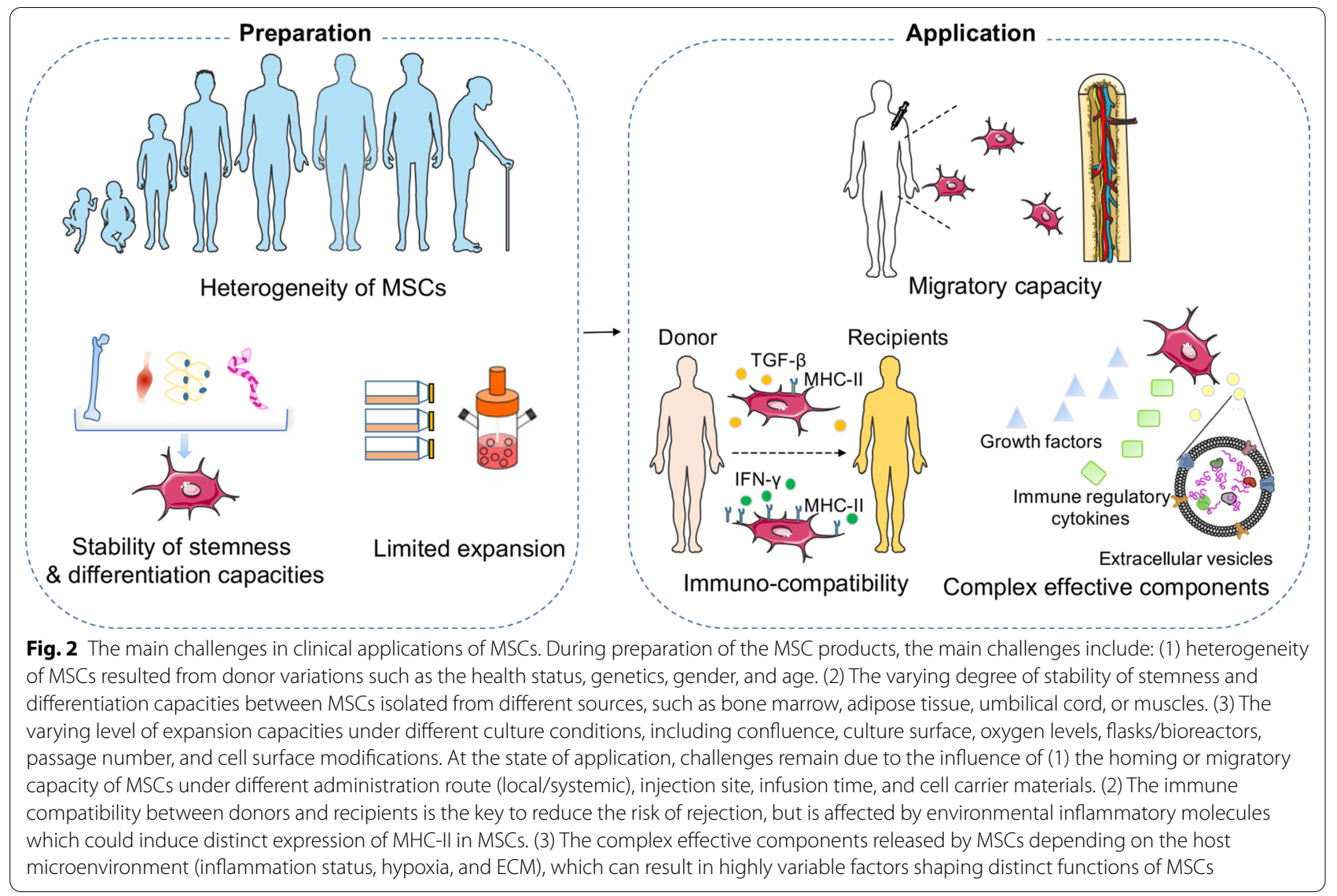

CD90, CD105, and CD106 in MSCs are down-regulated during culture expansion compared to MSCs in the stromal fraction [50]. The senescence-related proteins p53, p21, and p16 expressed under different conditions [51]. Rene et al. reported that after short-term in vitro culture, wild-type MSCs became senescent, and p21(-/-) p53(+/+) MSCs showed an elevated spontaneous apoptosis rate but no sign of tumoral transformation [52]. On the other hand, Mclean et al. discovered cancerassociated MSCs (CA-MSCs), which are determined by the expression of CD44, CD73, and CD90, exhibited the upregulation of the TGF- $\beta$ superfamily/bone morphogenetic protein (BMP) family [53], and MSCs harbored the potential to differentiate into cancer-associated fibroblasts (CAFs) at latter passages [54-57]. The malignant phenotypes of MSCs associated with CAFs could express Meflin, which is also a marker of MSCs maintaining their undifferentiated state [57-59].

To provide sufficient MSCs for clinical trials, MSCs need to be amplified in a large scale, which will inevitably face the issue of MSCs senescence and subsequent modifications of gene expressions [60]. Therefore, the long-term culture of MSCs often results in decreased proliferation and differentiation capacities and shortened life expectancy [61]. A standardized manufacturing process is essential for the success of clinical trials. Though the above molecules have been found to mediate the stemness of MSCs and regulate their differentiation, it remains challenging to control the fate of MSCs in a complex in vivo environment.

\section{Heterogeneity of MSCs}

Heterogeneity of MSCs is determined by multiple factors including but not limited to donors and tissue sources, cell populations, culture conditions, cell isolation techniques, cryoprotective and thawing protocols [62-64] (Fig. 3).

MSCs were defined as adherent cells with a spindleshaped morphology in standard culture conditions according to the minimal criteria developed by the International Society of Cell Therapy in 2006 [65]. They were characterized by the following features: (1) expression of CD105, CD73, and CD90, but no expression of CD45, CD34, CD14 or CD11b, CD79a, CD19, or HLA-DR; (2) capacity to differentiate into osteoblasts, adipocytes, and chondroblasts in vitro. However, these criteria were insufficient to define MSCs as variations exist at multiple levels. First, MSCs from different donors have distinct 
Table 2 Some typical stemness genes of MSCs

\begin{tabular}{|c|c|c|c|}
\hline Abbreviation & Names & Functional description & References \\
\hline HMGB1 & High Mobility Group Box 1 & Interacts with SDF-1 and CXCR4; required for tissue repairment & [30] \\
\hline KLF2 & Krüppel-like Factor 2 & $\begin{array}{l}\text { Enhances MSC proliferation; required for the maintenance of } \\
\text { stemness }\end{array}$ & [31] \\
\hline MCM2 & Minichromosome maintenance marker 2 & Required for cell division and DNA replication & [32] \\
\hline CCNA2 & Cyclin A2 & Regulates cell cycle & [33] \\
\hline PCNA & Proliferating cell nuclear antigen & $\begin{array}{l}\text { Recruits and retains many enzymes required for DNA replication } \\
\text { and repairment }\end{array}$ & [34] \\
\hline POLA1 & DNA Polymerase Alpha 1 & Required for DNA replication & [35] \\
\hline POLD1 & DNA Polymerase Delta 1 & Required for DNA replication & [36] \\
\hline RFC4 & replication factor $C$ subunit 4 & Required for DNA replication & {$[37]$} \\
\hline MAD2L1 & mitotic arrest-deficient 2 like 1 & Executes mitotic checkpoint & [38] \\
\hline CDK1 & Cyclin-Dependent Kinase 1 & $\begin{array}{l}\text { A catalytic subunit of a protein kinase complex that induces cell } \\
\text { entry into mitosis }\end{array}$ & [39] \\
\hline CCNB1 & Cyclin B1 & Predominantly expressed in the G2/M phase of cell division & [40] \\
\hline CDC45 & Cell Division Cycle 45 & $\begin{array}{l}\text { An important component of the replication fork, in DNA unwind- } \\
\text { ing }\end{array}$ & [41] \\
\hline TUBA1B & Tubulin Alpha $1 \mathrm{~b}$ & $\begin{array}{l}\text { Mitosis, cell movement, intracellular movement, and other biologi- } \\
\text { cal processes }\end{array}$ & [42] \\
\hline $\mathrm{E} 2 \mathrm{~F} 1$ & E2F Transcription Factor 1 & Promotes proliferation or apoptosis in response to DNA damage & [43] \\
\hline BIRC5 & Baculoviral IAP Repeat Containing 5 & Regulates apoptosis & [44] \\
\hline BLM & Bloom syndrome, RecQ helicase-like & Maintains genome integrity & [45] \\
\hline ITGAV & Integrin Subunit Alpha V & Belongs to $a-V$ integrin family, required for cell surface adhesion & [46] \\
\hline MAD2L1 & Mitotic spindle assembly checkpoint protein MAD2A & Required for chromosomes alignment at metaphase plate & [47] \\
\hline
\end{tabular}

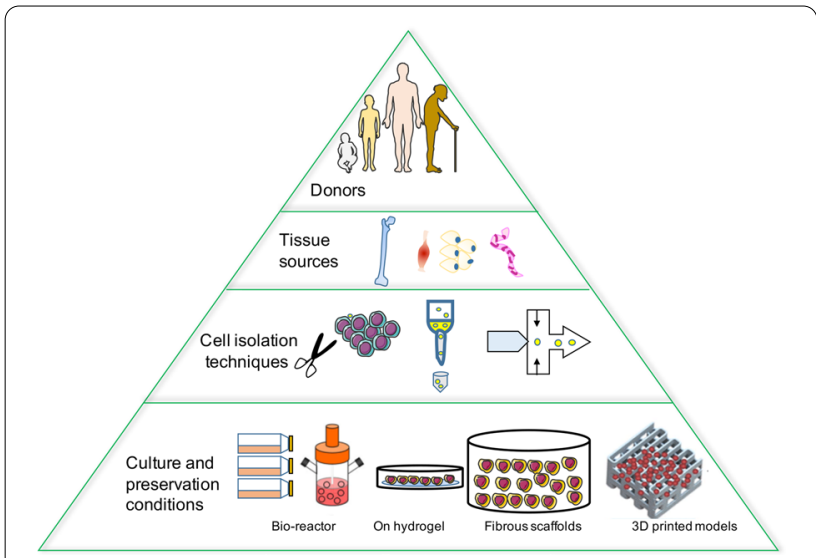

Fig. 3 MSCs exhibit heterogeneity at multiple levels. Heterogeneity of MSCs is determined by factors at multiple levels. (1) Donors at different health status, genetics, gender, and age may result in variations. (2) Tissue from different sources exhibits distinct characteristics, therefore leading to heterogeneity. (3) Cell isolation techniques may lead to distinct purity and sub-populations. (4) Cell culture environment and preservation conditions could affect the expansion and states of MSCs, therefore also affecting the heterogeneity functions due to differences in age, health condition, and other individual characteristics. Second, MSCs from different tissues ranging from adipose tissue to bone marrow could be distinct in terms of surface markers and differentiation capacities. This variation probably results from different biological, chemical, and mechanical stresses in stem cell niches, though the culture conditions are similar in vitro. Moreover, MSCs form clones, and cell heterogeneity exists both inter-clonally and intra-clonally. Extracellular matrix genes and osteogenic transcription factor-related genes show increased expression in highly osteogenic clones compared to poor osteogenic clones. Cell morphology and differentiation ability within one clone can also be remarkably different. For instance, cells located at the outer periphery express higher levels of genes related to cell proliferation (MKI67 and PODXL), while extracellular matrix genes (VCAM1) tend to be expressed in interior MSCs [66].

To identify specific cell subsets in heterogeneous MSCs, researchers have been continuously exploring characteristic cell surface markers and molecular signatures. Single cell-derived colony with rapidly dividing cells shows high colony-forming efficiency. STRO-1, CD146, and CD271 have been identified as cell surface markers for this subset [67]. However, cell subsets sharing similar surface markers would exhibit different chondrogenic 
differentiation capacities even under the same culture conditions [68]. RNA sequencing and microarray analysis have showed transcriptional signals predicting differentiation potential. Osterix and distal-less homeobox 5 are the main transcription factors involved in osteoblast differentiation, while peroxisome proliferator-activated receptor gamma (PPAR- $\gamma$ ) and CCAAT/enhancer-binding protein alpha are associated with adipogenic potential [69]. In addition, MSCs with specific surface markers of differentiation potential may present various physiological functions [70]. For example, CD105+ MSCs exhibited myogenic potential assisting the repairment of the infarcted myocardium [71], while CD106 + MSCs showed enhanced multipotency and immunosuppressive ability [72]. Increasing evidence shows that MSCs comprise multiple subsets with specific surface markers. More work is needed to define these subpopulations based on biomarkers and biological functions.

\section{Directed migratory capacity of MSCs}

The therapeutic efficacy of MSCs is highly dependent on their in vivo migration and homing capacities. The migrating direction is determined by chemokine receptors expressed on MSCs and chemokines in tissues [73]. Freshly isolated MSCs have a good homing effect, which is decreased after somatic expansion. For example, the chemokine receptor CXCR4 is highly expressed on primary bone marrow MSCs, but gradually lost with passages, resulting in the less recognition of its ligand CXCL12 (also known as SDF-1 $\alpha$ ) [74, 75]. Together, the primary MSCs are expected to have a better therapeutic efficacy due to more potent migration capacity.

However, the expression profile of chemokines in damaged tissues is often not compatible with that of receptors on MSCs. For instance, CXCL1, CXCL2 and CCL7 increased in infarcted myocardium, while expression of corresponding receptors (CCR1 and CXCR2) on MSCs was very low, resulting in low efficiency in the migration of MSCs to infarct sites [76]. To improve the migration rate, MSCs are genetically modified to express specific chemokine receptors [73]. For example, CCR7-modified MSCs efficiently migrated to secondary lymphoid organs and demonstrated significant clinical efficacy in the GVHD mouse model [77, 78]. CXCR5-modified MSCs migrated to the damaged sites by binding to CXCL13, which was highly expressed in damaged tissues [79]. Taken together, genetically modified MSCs are an independent treatment entity and could be used as targeted therapy.

The delivery of MSCs emerges as a prerequisite to the unfoldment of their full therapeutic potential. Different delivery routes could affect cell homing, survival, and paracrine function. Systemic delivery is considered a reasonable approach. However, the reported effect in terms of homing rate, survival rate, and maintenance of cellular function was modest and transient [80] for reasons including poor migration rate from vessels to tissues and high retention rate in the liver, lungs, and spleen [81]. In contrast to intravenous delivery, intra-tissue or intraorgan delivery showed higher delivery retention and efficiency, as evidenced by a large body of studies [82]. However, clustering of MSCs and occlusions in microvasculature has been reported in some disease models such as myocardial infarction [83]. Walczak et al. reported that only cells with a diameter between 20 and $50 \mu \mathrm{m}$ could avoid intracerebral entrapment [84]. Therefore, to maximize therapeutic efficacy, both the migratory capacity of MSCs and appropriate delivery methods should be considered.

\section{Limited expansion of MSCs}

Theoretically, MSCs can be expanded in vitro in traditional culture plates and flasks to any amount that meets experimental purpose. However, with prolonged culture duration and increased passage numbers, MSCs reach the Hayflick limit, exhibiting a marked decrease in proliferation with a transformation in morphology from a thin spindle shape to a flattened square shape. The cell density seeded in the culture containers also plays a role in the senescence of MSCs. Neuhuber et al. found the optimal cell growth of rat MSCs at 200 cells per $\mathrm{cm}^{2}$ compared with 20 cells or 2000 cells per $\mathrm{cm}^{2}$ [85]. In other studies, a relatively low density $\left(\sim 1.5-200\right.$ cells per $\left.\mathrm{cm}^{2}\right)$ was suggested to support better proliferation [86]. Alterations in autocrine secretion and contact inhibition may contribute to the slow growth at high density.

Large-scale expansion in 2D plates over long term also impacts stem cell characteristics of MSCs. According to Zhao et al., hUC-MSCs at various passages have multiple mutation spectra on signatures and functions, and cells at high passage showed declined therapeutic effect in aGVHD mouse model [87]. It has been shown that chondrogenic differentiation of MSCs in 2D culture is less efficient than that of MSCs in 3D culture [88]. Therefore, 3D expansion of MSCs was developed to prevent phenotypic changes caused by monolayers, where a broad and flattened morphology upon passaging was well preserved.

Moreover, MSCs have shown the capacity to differentiate into numerous cell types such as neural cells, hepatocyte-like cells, and pancreatic islet-like cells [89, 90]. The transient differentiation of MSCs into neural precursor-like cells may experience de-differentiation during extended culture [91]. Therefore, in vitro induction is often insufficient to yield pure functionally competent cells. 
Taken together, developing the technique that can produce a huge number of cells rapidly and cost-effectively with guaranteed cell quality is paramount for the clinical progress of MSCs.

\section{Effective components of MSC treatments}

The secretion of cytoprotective factors by MSCs was first reported by Gnecchi and colleagues. They observed that Akt-MSCs (MSCs overexpressing Akt) prevented ventricular remodeling and improved the heart function following surgical myocardial infarction (MI). Since cell transplantation and myogenic pathways would be ineffective over such a brief interval, a new mechanism was proposed that the injected MSCs might act through releasing trophic factors that contribute to myocardial protection following an ischemic insult. This hypothesis was then confirmed by evident improvements in cardiac performance following injection of conditioned medium (CM) collected from hypoxic Akt-MSCs into an induced MI model, which protected ventricular cardiomyocytes with less apoptosis when subjected to a hypoxic condition [92].

In 2007, Dai et al. observed that MSCs-CM had a similar, albeit less intense, effect of MSCs in myocardial infarction, indicating that at least part of the effect observed following MSCs injection could be attributed to soluble factors [93]. In the context of neuronal damage, it has been established that the presence of BDNF, GDNF, NGF, and IGF in the MSCs secretome is necessary for the neuronal survival in vitro and in vivo $[94,95]$. MSCs$\mathrm{CM}$ has demonstrated therapeutic efficacy in some other disease models including chronic kidney disease, certain lung, and liver diseases [96, 97].

The paracrine effects of MSCs as an initial mechanism of action inspired further biological analysis of MSCs secretome [98]. Subsequent studies found more paracrine effectors, including soluble cytokines, growth factors, hormones, miRNAs, or lncRNAs that targeting a variety of cells such as immune cells and injured tissue cells [99]. In addition, the paracrine effectors could be loaded in extracellular vesicles (EVs) and exerted longterm effects [100]. In accordance, many studies have shown that MSC-derived EVs retain the biological activity of parental MSCs. It has been demonstrated that EVs showed a similar therapeutic effect as MSCs in selected animal models [101]. However, different studies found various effective components of MSCs in specific animal models and human diseases, and the interactions and functional differences between effectors remain elusive. Therefore, novel in-depth analytical techniques and platforms are warranted to investigate the MSCs secretome in the future.

\section{Attempts to improve the therapeutic outcomes of MSCs}

Although there were no attributable serious adverse events after MSC therapy, fever within $24 \mathrm{~h}$ and temporary pain at the injection sites are commonly occurred. Here we summarize four strategies to limit adverse events related to MSC treatments and improve the therapeutic outcomes, including genetic modifications or priming strategies to change the inherent characteristics of MSCs, and biomaterial strategies to modify the outside circumstances, and the usage of MSCs secretome (Fig. 4).

\section{Biomaterial strategies to maintain more homogeneous MSCs}

Biomaterials for delivering MSCs have been extensively investigated. These materials showed advantages in offering a scaffold for the adherence and survival of MSCs, as well as preserving the functional components MSCs secreted, thus elongating the effective durations in clinical treatment. However, the implantation of biomaterials could induce the foreign-body responses (FBR) in the host immune system, which can potentially result in fibrosis and failure of the implantation. Therefore, biomaterials suitable for MSCs were constructed to ameliorate the FBR and subsequent fibrotic encapsulation [102]. For example, loading MSCs with small-molecule encapsulating microparticles (MPs) can boost the duration of the products. MPs are composed of biocompatible materials that can be therapeutically tuned according to their composition, polymer molecular weight, drug loading, and release capacities [103]. MSCs loaded with degradable budesonide-containing MPs exhibited fourfold increase in IDO activity in vitro compared to MSCs without being pre-treated with budesonide [104]. This led to a twofold improvement in the suppression of peripheral blood mononuclear cells (PBMCs) activation following IFN- $\gamma$ stimulation [105].

MSCs are typically delivered to a graft site using a decellularized extracellular matrix (ECM) scaffold. The advent of synthetic polymers has revolutionized tissue engineering. These polymers are highly tunable, homogenous, and cell-free materials and have a high batch-tobatch consistency taking the form of porous hydrogels, sponges, plates, or membranes [106, 107]. However, their unique properties could exert different influences on MSCs function. Table 3 summarizes the influence of biomaterials properties on the function of MSCs, including dimensionality, stiffness, topographical cues, surface chemistry, and microstructure of biomaterials. 


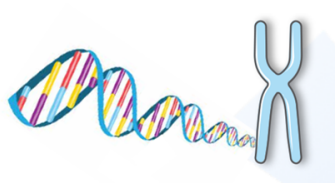

Viral transduction/ transfection CRISPR/Cas9 modification

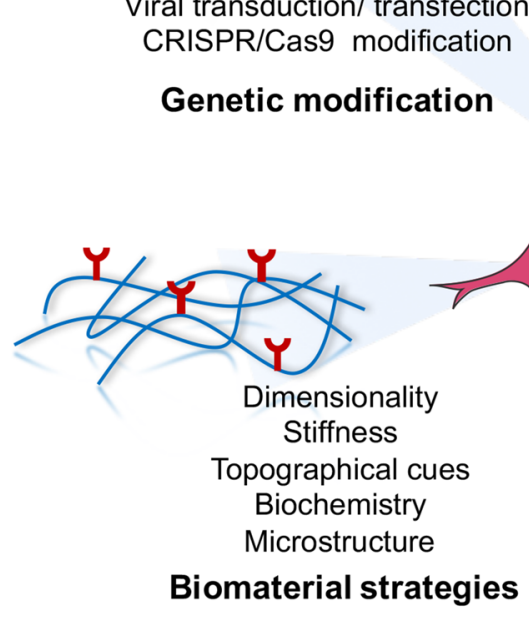

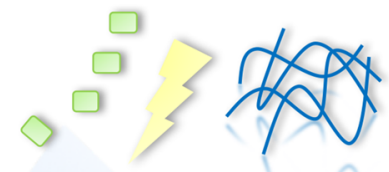

Small molecules Hypoxia

Biomaterials

Priming MSCs

Fig. 4 Current attempts to improve MSC treatment. To improve the therapeutic efficiency of MSCs treatment, modification was made mainly in the following aspects: (1) genetic modification of MSCs by viral transduction or CRISPR/Cas9 techniques to engineer MSCs with enhanced homing, potency, or expansion capacities; (2) priming MSCs with small molecules, hypoxia, or structural stimulations by biomaterials to improve MSC function, survival, and therapeutic efficacy, thus boosting their therapeutic efficacy; (3) biomaterial strategies to improve the survival and function of MSCs by offering a scaffold for MSCs adherence, including modifications on dimensionality, stiffness, topographical cues, surface chemistry, and microstructure of biomaterials. (4) Utilize the MSCs secretome as a drug delivery platform for treatment

\section{Genetic modification to produce MSCs with desired biologic function Viral DNA transduction and $m R N A / D N A$ transfection}

To further optimize the therapeutic efficacy of MSCs, MSCs have been genetically engineered to produce trophic cytokines or other beneficial gene products in numerous preclinical models by transfecting MSCs with viral or non-viral vectors. Over the last few decades, these MSCs have successfully been engineered to express therapeutic peptides and proteins in animal models [119]. For instance, MSCs expressing thioredoxin-1 (Trx1, a powerful antioxidant, transcription factor and growth factor regulator) improved cardiac function in post-myocardial infarction rat models [120]. MSCs expressing IL-12 showed potent anticancer activity against melanoma, breast cancer, and hepatoma $[121,122]$. And MSCs expressing interferon- $\gamma$ inhibited tumor growth in mouse neuroblastoma and lung carcinoma models [123, 124]. In line with these advances achieved in animal models, several MSCs-based therapies are under clinical development (Table 4).

However, both viral and non-viral vectors have some limitations. Non-viral vectors present transient gene expression and low-transfection efficiency, while viral transduction is associated with a higher risk of chromosomal instability, insertional mutagenesis, and proto-oncogene activation despite the inherent high transfection efficiency [125]. The adverse immune reactions induced by viral transduction were reported to impair the stability of transgenes [126, 127]. Therefore, the limitations and adverse responses should be valued when modifying MSCs by transfection.

Some studies made attempts on human-induced pluripotent stem cell (iPSC)-derived MSCs to obtain improved expandability. Actually, therapeutic transgenes could be inserted into iPSC-derived MSCs before MSCs derivation. This strategy could eliminate insertional mutation as well as guarantee stable expression of transgenes during prolonged expansion [128]. So iPSC-derived MSCs may be a candidate of MSCs for usage. 


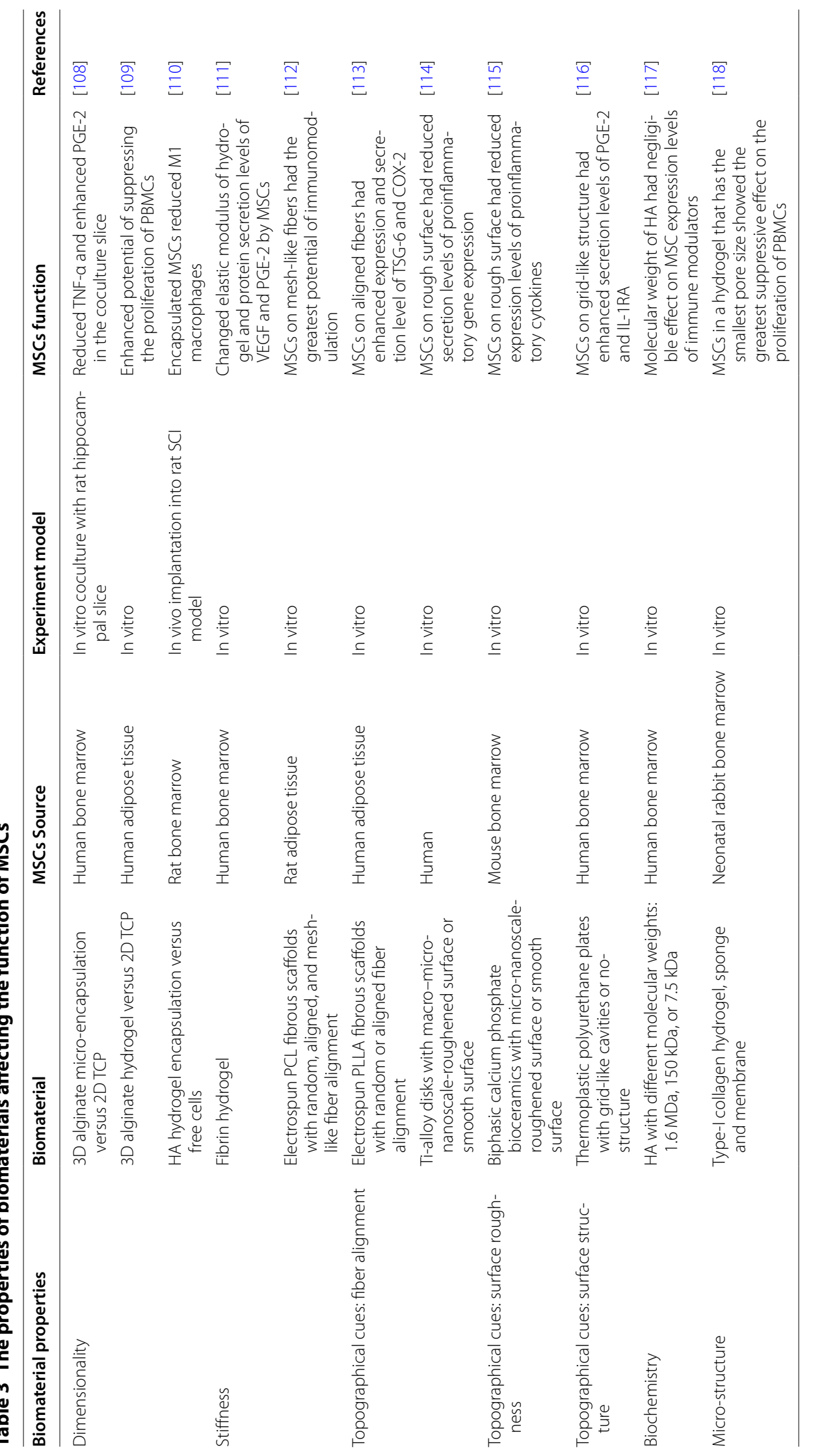


Table 4 Engineered MSCs for treatment reaching the clinical stage

\begin{tabular}{|c|c|c|c|c|c|c|}
\hline Delivery system & $\begin{array}{l}\text { Administration } \\
\text { route }\end{array}$ & Sponsor & Indication & $\begin{array}{l}\text { Development } \\
\text { phase }\end{array}$ & Status & NCT number \\
\hline $\begin{array}{l}\text { MSCs secreting } \\
\text { IFN- } \beta\end{array}$ & Intraperitoneal & $\begin{array}{l}\text { M.D. Anderson } \\
\text { Cancer Center, } \\
\text { Dallas TX }\end{array}$ & Ovarian cancer & Phase 1 & $\begin{array}{l}\text { Active, not recruit- } \\
\text { ing }\end{array}$ & NCT02530047 \\
\hline $\begin{array}{l}\text { MV-NIS infected } \\
\text { adipose tissue- } \\
\text { derived MSCs }\end{array}$ & Intraperitoneal & $\begin{array}{l}\text { Mayo Clinic, Roches- } \\
\text { ter MN }\end{array}$ & $\begin{array}{l}\text { Recurrent ovarian } \\
\text { cancer }\end{array}$ & Phase 1/2 & Recruiting & NCT02068794 \\
\hline $\begin{array}{l}\text { Bone marrow- } \\
\text { derived autolo- } \\
\text { gous MSCs } \\
\text { infected with } \\
\text { ICOVIR5, an onco- } \\
\text { lytic adenovirus } \\
\text { (CELYVIR) }\end{array}$ & Intravenous & $\begin{array}{l}\text { Hospital Infantil } \\
\text { Universitario Niño } \\
\text { Jesús, Madrid, } \\
\text { Spain }\end{array}$ & $\begin{array}{l}\text { Metastatic and } \\
\text { refractory solid } \\
\text { tumors }\end{array}$ & Phase 1/2 & Completed & NCT01844661 \\
\hline $\begin{array}{l}\text { MSCs genetically } \\
\text { modified to } \\
\text { express TRAIL }\end{array}$ & Intravenous & $\begin{array}{l}\text { University College, } \\
\text { London }\end{array}$ & $\begin{array}{l}\text { Lung adenocarci- } \\
\text { noma }\end{array}$ & Phase 1/2 & Recruiting & NCT03298763 \\
\hline $\begin{array}{l}\text { Autologous human } \\
\text { MSCs geneti- } \\
\text { cally modified to } \\
\text { express HSV-TK }\end{array}$ & Intravenous & $\begin{array}{l}\text { Apceth GmbH \& Co. } \\
\text { KG, Germany }\end{array}$ & $\begin{array}{l}\text { Advanced gastroin- } \\
\text { testinal cancer }\end{array}$ & Phase 1/2 & Completed & $\begin{array}{c}\text { 2012-003,741- } \\
15 \text { (EudraCT } \\
\text { number) }\end{array}$ \\
\hline
\end{tabular}

\section{CRISPR-Cas9 technology to obtain highly homogeneous MSCS}

With CRISPR/Cas9 technology, genetic modification of MSCs can be done with higher efficiency and specificity [129]. Compared to transcription activator like effector nuclease (TALEN) and the zinc-finger nucleases (ZFNs), CRISPR/Cas9 technology is faster, more economically efficient, and user-friendly [130]. CRISPR/Cas9-based gene manipulation has been widely employed in stem cell field particularly MSCs research, including gene knockin, knock-out, activation or silence, etc.

CRISPR/Cas9-mediated gene knockdown in MSCs has been proved effective in treating diseases such as myocardial infarction [131]. Targeted gene knock-in promoted the differentiation capacity of MSCs and, in turn, ameliorated the insufficiency of functional cells in local sites [132]. Genetically modified MSCs have been evaluated in clinical trials. The TREAT-ME-1 study, an open-label, multicenter, and first-in-human Phase $1 / 2$ trial, evaluated the safety, tolerability, and efficacy of genetically modified autologous MSC-apceth-101 treatment in patients with advanced gastrointestinal adenocarcinoma [133]. Further investigations are still needed to obtain unequivocal evidence on the differentiation and regeneration potentials of MSCs in vivo. Moreover, next-generation sequencing and genotypic techniques might serve as a new paradigm to improve the efficacy on targeting specific cell types for personalized medicine. CRISPR gene-engineered MSCs studies are illustrated in Table 5.

Despite the specificity of CRISPR/Cas technology in gene delivery [143], only one clinical trial of
MSCs modified with CRISPR/Cas9 has been registered (NCT03855631).

\section{"Priming" MSCs with small molecules to exogenously boost their therapeutic function}

Given current manufacture of MSCs cannot meet the requirement for clinical trials in terms of production scale, the alternative is to boost the function of limited cells through priming MSCs. Priming has also been referred to as licensing or preconditioning, which is a concept commonly used in the field of immunology, and it has been adapted to the scope of stem cells [144, 145]. One of the commonly used strategies is priming MSCs with pro-inflammatory mediators, including IFN- $\gamma$, TNF$\alpha$, IL- $1 \alpha$, and IL- $1 \beta$, and more priming approaches are being proposed to improve the function, survival, and therapeutic efficacy of MSCs [146, 147]. The priming approaches could be divided into three categories based on the stimulations: (a) MSCs priming with small molecules, (b) MSCs priming with hypoxia, (c) MSCs priming with biomaterials. Table 6 summarizes some representative priming MSCs.

"Priming" MSCs resulted in exogenously boosted therapeutic function in comparison with original state. Several "primed" MSC products have been applied clinically, with the most notable being NurOwn from Brainstorm Cell Therapeutics Company. NurOwn boosted the expression of multiple neurotrophic factors (NTFs) including GDNF, BDNF, VEGF, and HGF [173]. When administered to patients with neurodegenerative diseases, NurOwn delivered multiple NTFs as well as the 
Table 5 The tests of modified MSCs using CRISPR-Cas9 technology

\begin{tabular}{|c|c|c|c|}
\hline Source of MSCs & Gene & Outcome & References \\
\hline Human umbilical cord-derived MSCs & MCP-1/CCL2 & $\begin{array}{l}\text { CCL2-overexpressing hUC-MSCs showed better } \\
\text { functional recovery relative to naïve hUC- } \\
\text { MSCs, promoting subsequent endogenous } \\
\text { brain repair }\end{array}$ & {$[134]$} \\
\hline Human pancreatic ductal tissue MSCs & PTEN gene & $\begin{array}{l}\text { PTEN mRNA synthesized in vitro is capable of } \\
\text { being applied to a MSC-mediated anticancer } \\
\text { strategy for the treatment of glioblastoma } \\
\text { patients }\end{array}$ & {$[135]$} \\
\hline Mouse bone marrow MSCs & SV40T into a safe harboring site at Rosa26 locus & $\begin{array}{l}\text { CRISPR/Cas9 HDR-mediated immortalization of } \\
\text { BMSCs can be more effectively reversed than } \\
\text { that of retrovirus-mediated random integra- } \\
\text { tions }\end{array}$ & {$[136]$} \\
\hline Human bone marrow MSCs & Promotor of ectodysplasin (EDA) & $\begin{array}{l}\text { After transfection with sgRNA-guided dCas9-E, } \\
\text { the BM-MSCs acquired significantly higher } \\
\text { transcription and expression of EDA by doxy- } \\
\text { cycline (Dox) induction }\end{array}$ & {$[137]$} \\
\hline Mouse bone marrow-derived MSCs & $\| \mathrm{L}-10$ & $\begin{array}{l}\text { Transplantation of CRISPR system engineered } \\
\text { IL10-overexpressing bone marrow-derived } \\
\text { MSCs for the treatment of myocardial infarc- } \\
\text { tion in diabetic mice }\end{array}$ & {$[138]$} \\
\hline Rat bone marrow MSCs & Smad7 & $\begin{array}{l}\text { Smad7-MSCs is effective in treating liver fibrosis } \\
\text { in the CCl4-induced liver cirrhosis model via } \\
\text { inhibition of TGF- } \beta 1 \text { signaling pathway }\end{array}$ & {$[139]$} \\
\hline Human mesenchymal stem cells & First intron of the PPP1R12C gene & $\begin{array}{l}\text { exogenous gene hFIX was effectively expressed } \\
\text { following site-specific targeting into the } \\
\text { AAVS1 locus in MSCs; MSCs may be used } \\
\text { as potential cell carriers for gene therapy of } \\
\text { hemophilia B }\end{array}$ & {$[140]$} \\
\hline $\begin{array}{l}\text { Immortalized human bone marrow } \\
\text { MSC cell line (ATCC PCS-500-041) }\end{array}$ & PUMILIO2 (PUM2) & $\begin{array}{l}\text { Depletion of PUM2 blocks MSC adipogenesis } \\
\text { and enhances osteogenesis. PUM2 works as a } \\
\text { negative regulator on the 3' UTRs of JAK2 and } \\
\text { RUNX2 via direct binding. CRISPR/CAS9-medi- } \\
\text { ated gene silencing of Pum2 inhibited lipid } \\
\text { accumulation and excessive bone formation }\end{array}$ & {$[141]$} \\
\hline Human bone marrow-MSCs & Platelet-derived growth factor B (PDGF-B) & $\begin{array}{l}\text { PDGFB-MSCs increased anti-apoptotic signal- } \\
\text { ing and exhibited enhanced survival and } \\
\text { expansion after transplantation, resulting in an } \\
\text { enlarged humanized niche cell pool that pro- } \\
\text { vide a better humanized microenvironment to } \\
\text { facilitate superior engraftment and prolifera- } \\
\text { tion of human hematopoietic cells }\end{array}$ & {$[142]$} \\
\hline
\end{tabular}

immunomodulatory components secreted by MSCs. This combination demonstrated impressive therapeutic efficacy in a phase 2 clinical trial (NCT02017912), in which ALS patients got reduced ALS progression 24 months after NurOwn infusion compared to the controls [174]. So the indication of NurOwn has been expanded to include multiple sclerosis.

However, priming approaches of MSCs still have many limitations in clinical translation, such as induction of immunogenicity, high costs, variable effects, and lack of good manufacturing practices (GMP) suitable for clinical application [175]. Moreover, the long-term effect of priming MSCs has not been evaluated yet. Further studies are needed to evaluate (1) the effects of different priming approaches in clinic; (2) the best sources for MSCs isolation; (3) the epigenetic modifications, immunogenicity, and tumorigenicity of primed and non-primed MSCs; and (4) the appropriate GMP standards for quality control of MSC products, including quality of cryopreserved primed-MSCs at different passages.

\section{Utilize the MSCs secretome as a drug delivery platform for treatment}

The "secretome" of MSCs, including secretory proteins such as growth factors, cytokines, and chemokines and EVs such as microvesicles (MVs; 100-1000 nm diameter) and exosomes (40-150 nm diameter), has been shown to 


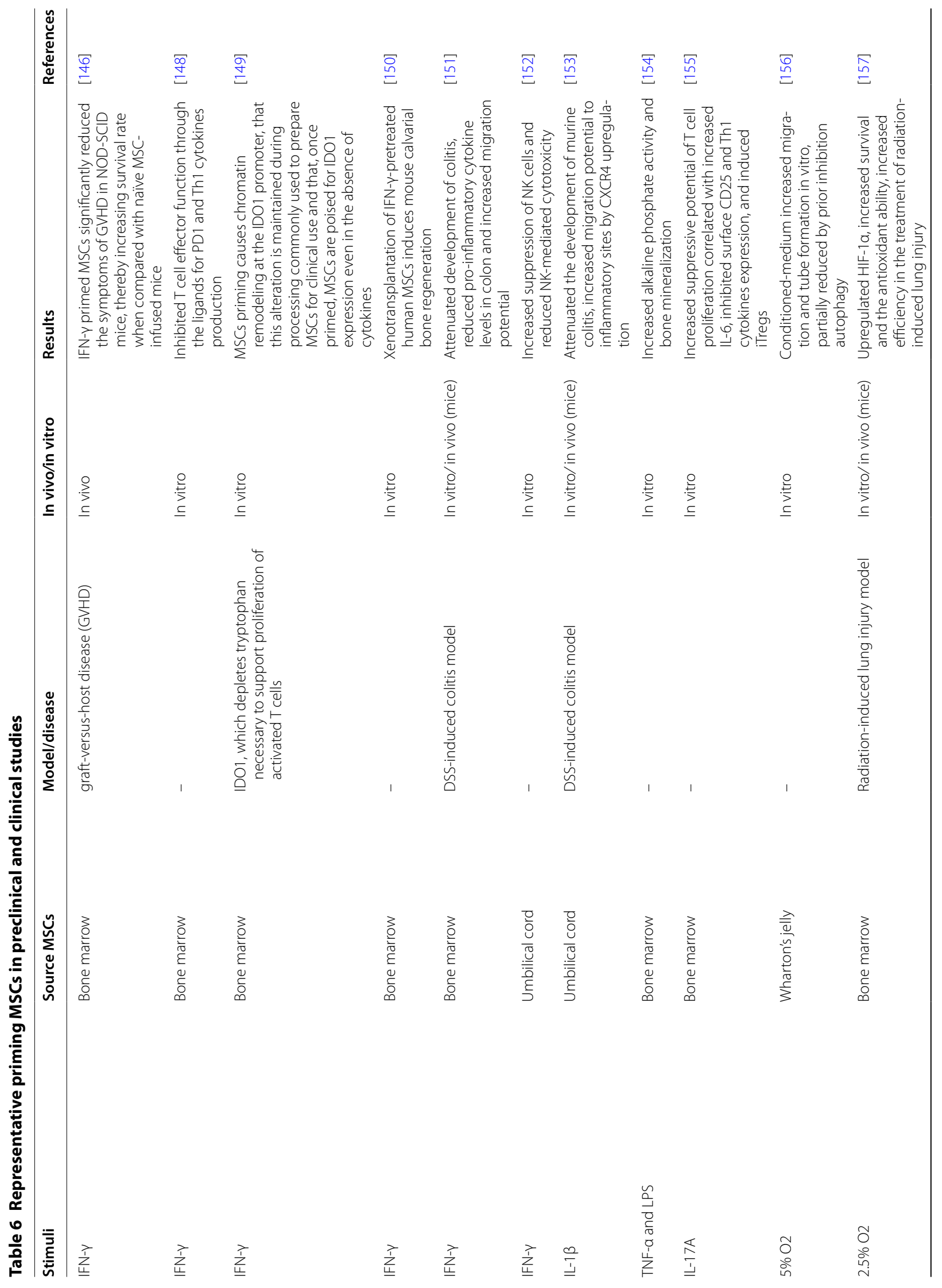




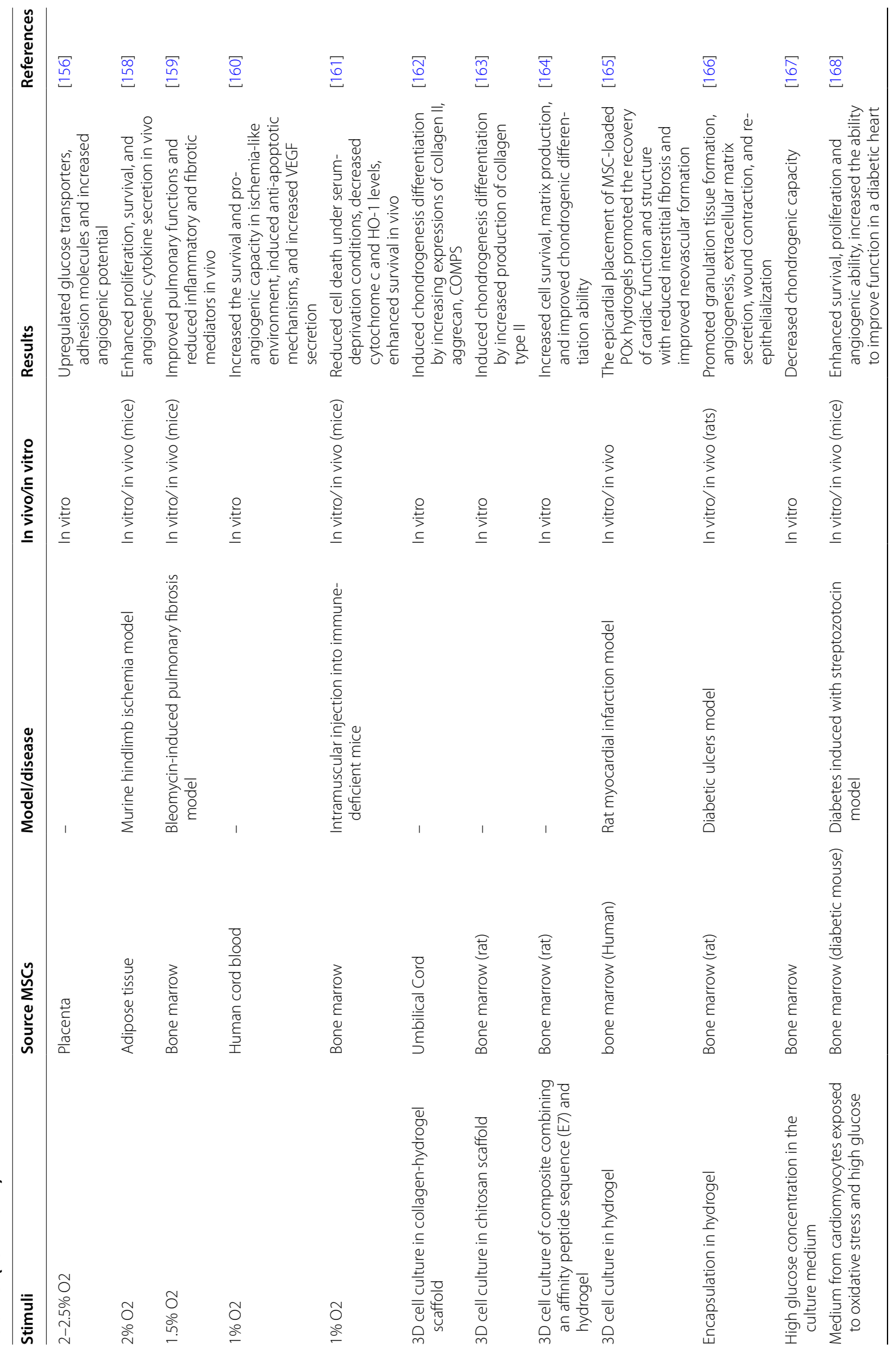




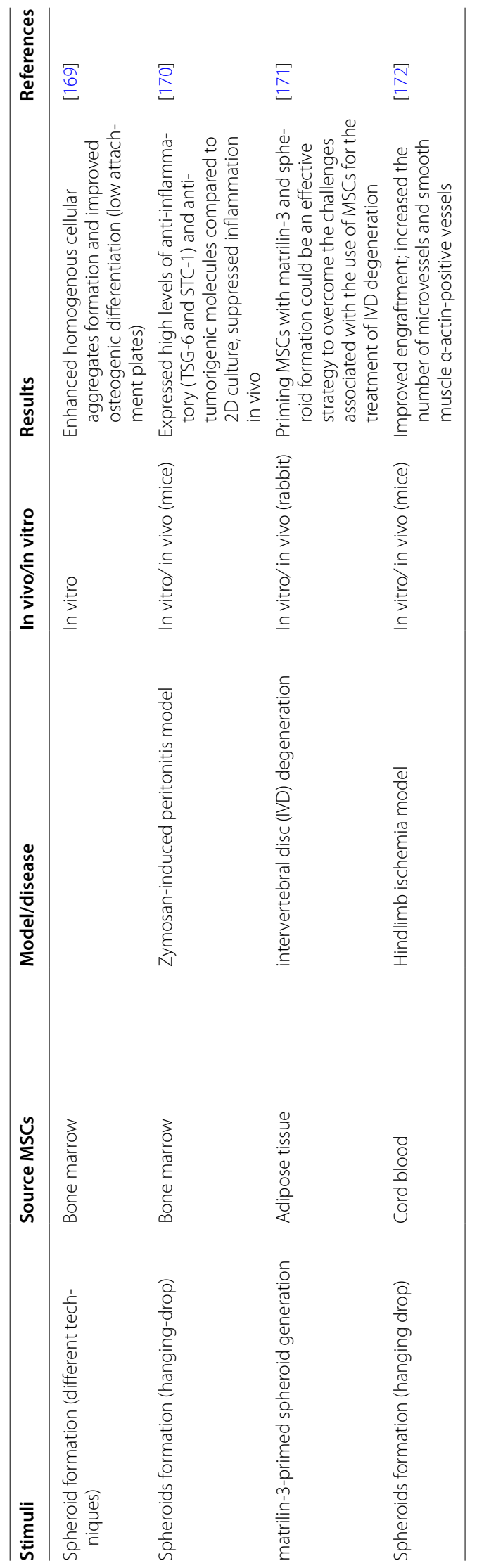


exhibit many of the therapeutic properties of MSCs. For example, MSC-derived EVs have demonstrated similar or even superior therapeutic capacity for autoimmune diseases and neurodegenerative disorders compared with their parental MSCs $[176,177]$. They also have better safety profiles due to their better immunocompatibility. In addition, they can bypass the endothelial layers in the blood-brain barrier or blood-retinal barrier, providing an ideal cargo to deliver biomolecules to the central nervous system [178].

Several studies have demonstrated the clinical effectiveness of MSC-EVs. For example, hBMMSC-EVs revealed significant improvements in patients suffering from refractory graft-versus-host disease [179]. In another study, administration of hUCMSC-EVs resulted in overall improvement in patients with grade III-IV chronic kidney disease [180]. Nassar et al. conducted a clinical trial to assess the effects of hUCMSC-EVs on pancreatic islet beta cell mass in Type-1 diabetic patients (NCT02138331). And there are other ongoing trials conducted to determine the safety and efficacy of human MSC-EVs in ocular diseases such as promoting the healing of large and refractory macular holes (NCT03437759) and relieving dry eye symptoms in oGVHD patients (NCT04213248). Moreover, MSC-EVs have been modified to load small molecules. For example, miR-124 was loaded in exosomes to treat patients with acute ischemic stroke (NCT03384433).

\section{Advances and perspectives to overcome challenges in MSC clinical application Artificial intelligence (AI) in MSC treatment}

Digital technology and AI are driving the revolution of healthcare industry [181]. The drug research and development became an important application field of AI technology [182]. AI in de novo design has successfully produced biologically active molecules with desired properties [183]. The discovery of drug molecules by AI has been selected as one of the "top ten global breakthrough technologies" by MIT Technology Review in 2020. The advances of AI are likewise expected to boost the understanding of MSCs therapies and help identifying the essential elements of MSCs.

AI can find new molecular compounds and emerging drug targets much faster than traditional methods, thus speeding up the progress of drug development [184, 185]. At the same time, AI can more accurately predict the follow-up experimental results of new drugs, so as to improve the accuracy at each stage of drug development [186]. Computer-aided drug design techniques are thus revolutionizing MSCs therapies.
To understand the essential elements in MSCs treatment, AI may recognize the dynamic molecular characteristics of essential elements, which include different protein sequences, molecular structures, as well as the binding forces and stabilities between targeted molecules and cell receptors. These data could be used to train a predictive model to the utmost accuracy [187]. Predicted elements may also be produced under AI guidance. Powered by a robotic platform, a system developed by MIT researchers partially automates the production of small molecules that could be used in medicine, solar energy, and polymer chemistry. Reportedly, the new system combines three main steps. First, software guided by AI proposes a route for synthesizing a molecule, then chemical experts review this route and refine it into a chemical "recipe," and lastly, the recipe is sent to a robotic platform that automatically assembles the hardware and performs the reactions that build the molecule [188].

At present, the pharmaceutical world is increasingly engaged in technologies to shorten the time required to identify new drugs and repurpose current drugs. Since MSC therapies showed beneficial effects with complex undetermined components, AI may be well-suited to analyzing and revealing essential elements. Companies such as Merck, GSK, and Roche have developed partnerships with AI companies to construct suitable platforms $[189,190]$. However, the drug discovery process with AI is a long shot, which need to be verified in clinical trials.

\section{Engineered MSC-EVs for treatment}

Paracrine effect was discovered to mediate MSCs therapeutic efficacy in previous studies [191-193]. EVs are one of the major paracrine effectors, which are bilayer membrane structures transferring bioactive components [194]. The best-studied EVs can be classified into exosomes and microvesicles according to their sizes, shapes, biogenesis, origins, and compositions $[195,196]$. Due to their liposome-like structures reflecting biophysical characteristics of the parental cells, EVs are stable in vivo compared to other foreign particles [197]. Moreover, it is relatively easy to modify and/or improve the contents of EVs and their surface properties to enhance the therapeutic potential or to act as a drug delivery system [198]. These advantages make EVs promising for clinical treatment. Currently, there are 15 clinical trials registered in ClinicalTrial.gov (Table 7). However, none has been completed and challenges remained for the practical application of EVs.

First of all, the manufacture of large scales of MSCEVs with high purity is difficult. MSC-EVs are isolated from MSC culture media, of which conditions including the seeding cell number, media volume, and isolation method and time of EVs can influence both the quantity 
Table 7 The registered clinical trials of treatment using EVs or exosomes derived from MSCs

\begin{tabular}{|c|c|c|c|c|c|}
\hline NCT number & Title & Status & Condition & Phase & Start date \\
\hline NCT04173650 & $\begin{array}{l}\text { MSC EVs in Dystrophic Epidermolysis } \\
\text { Bullosa }\end{array}$ & Not yet recruiting & Dystrophic Epidermolysis Bullosa & $\begin{array}{l}\text { Phase } 1 \\
\text { Phase } 2\end{array}$ & Sep-2020 \\
\hline NCT04276987 & $\begin{array}{l}\text { A Pilot Clinical Study on Inhalation of } \\
\text { Mesenchymal Stem Cells Exosomes } \\
\text { Treating Severe Novel Coronavirus } \\
\text { Pneumonia }\end{array}$ & Completed & Coronavirus & Phase 1 & Feb-2020 \\
\hline NCT02138331 & $\begin{array}{l}\text { Effect of Microvesicles and Exosomes } \\
\text { Therapy on cell Mass in Type I Diabe- } \\
\text { tes Mellitus (T1DM) }\end{array}$ & Unknown status & Diabetes Mellitus Type 1 & $\begin{array}{l}\text { Phase } 2 \\
\text { Phase } 3\end{array}$ & Apr-2014 \\
\hline NCT04313647 & $\begin{array}{l}\text { A Tolerance Clinical Study on Aerosol } \\
\text { Inhalation of Mesenchymal Stem Cells } \\
\text { Exosomes In Healthy Volunteers }\end{array}$ & Recruiting & Healthy & Phase 1 & Mar-2020 \\
\hline NCT03384433 & $\begin{array}{l}\text { Allogenic Mesenchymal Stem Cell- } \\
\text { Derived Exosome in Patients With } \\
\text { Acute Ischemic Stroke }\end{array}$ & Recruiting & Cerebrovascular Disorders & $\begin{array}{l}\text { Phase } 1 \\
\text { Phase } 2\end{array}$ & Apr-2019 \\
\hline NCT04223622 & $\begin{array}{l}\text { Effects of ASC Secretome on Human } \\
\text { Osteochondral Explants }\end{array}$ & Not yet recruiting & Osteoarthritis & - & Feb-2020 \\
\hline NCT04213248 & $\begin{array}{l}\text { Effect of UMSCs-Derived Exosomes on } \\
\text { Dry Eye in Patients With CGVHD }\end{array}$ & Recruiting & Dry Eye & $\begin{array}{l}\text { Phase } 1 \\
\text { Phase } 2\end{array}$ & Feb-2020 \\
\hline NCT03437759 & MSC-Exos Promote Healing of MHs & Recruiting & Macular Holes & Early Phase 1 & Mar-2017 \\
\hline NCT04356300 & $\begin{array}{l}\text { Exosome of Mesenchymal Stem Cells } \\
\text { for Multiple Organ Dysfunction Syn- } \\
\text { drome After Surgical Repair of Acute } \\
\text { Type A Aortic Dissection }\end{array}$ & Not yet recruiting & Multiple Organ Failure & Not Applicable & Sep-2020 \\
\hline NCT04388982 & $\begin{array}{l}\text { The Safety and the Efficacy Evaluation } \\
\text { of Allogenic Adipose MSC-Exos in } \\
\text { Patients With Alzheimer's Disease }\end{array}$ & Recruiting & Alzheimer Disease & $\begin{array}{l}\text { Phase } 1 \\
\text { Phase } 2\end{array}$ & Jul-2020 \\
\hline NCT03608631 & $\begin{array}{l}\text { Exosomes in Treating Participants with } \\
\text { Metastatic Pancreas Cancer with } \\
\text { KrasG12D Mutation }\end{array}$ & Not yet recruiting & $\begin{array}{l}\text { Metastatic Pancreatic } \\
\text { Adenocarcinoma|Pancreatic Ductal } \\
\text { Adenocarcinoma|Stage IV Pancreatic } \\
\text { Cancer }\end{array}$ & Phase 1 & Mar-2020 \\
\hline NCT04602442 & $\begin{array}{l}\text { Safety and Efficiency of Method of } \\
\text { Exosome Inhalation in COVID-19 } \\
\text { Associated Pneumonia }\end{array}$ & Enrolling by invitation & Covid19 & Phase 2 & Oct-2020 \\
\hline NCT04491240 & $\begin{array}{l}\text { Evaluation of Safety and Efficiency of } \\
\text { Method of Exosome Inhalation in } \\
\text { SARS-CoV-2 Associated Pneumonia }\end{array}$ & Completed & Covid19 & $\begin{array}{l}\text { Phase } 1 \\
\text { Phase } 2\end{array}$ & July 2020 \\
\hline NCT04602104 & $\begin{array}{l}\text { A Clinical Study of Mesenchymal Stem } \\
\text { Cell Exosomes Nebulizer for the Treat- } \\
\text { ment of ARDS }\end{array}$ & Not yet recruiting & Acute Respiratory Distress Syndrome & $\begin{array}{l}\text { Phase } 1 \\
\text { Phase } 2\end{array}$ & Oct-2020 \\
\hline NCT03857841 & $\begin{array}{l}\text { A Safety Study of IV Stem Cell-derived } \\
\text { Extracellular Vesicles (UNEX-42) in Pre- } \\
\text { term Neonates at High Risk for BPD }\end{array}$ & Recruiting & Bronchopulmonary Dysplasia & Phase 1 & June-2019 \\
\hline
\end{tabular}

and quality of EVs [199]. Therefore, optimization of culture methods (e.g., hypoxia, sheer stress, and bioreactor) combining with intensive evaluation of the pros and cons of the different EVs isolation methods is prerequisites for MSC-EVs to yield improvements. These procedures should be regulated and controlled to ensure the clinical-grade EVs production [200]. Recently, Mendt et al. reported using a bioreactor system in the GMP facility to obtain sterile, clinical-grade EVs from BM-MSCs. In that instance, the therapeutic effects of BM-MSCs on pancreatic cancer xenograft mouse models were evaluated, and feasible directions for clinical application of MSC-EVs were provided [201].

Safety and efficacy of MSC-EVs in various disease conditions need to be ensured in further preclinical and clinical evaluation. In vivo distribution analysis of fluorescence-labeled EVs has shown that MSC-EVs might have homing capacity for injured or tumor-bearing sites comparable as MSCs [202]. Long-term toxicity and immunogenicity of repetitive EVs administration using hematological examination, histopathological analysis, and immunotyping test should also be performed to find 
whether MSC-EVs might trigger immune responses or toxic reactions [203].

After the disclosure of precise mechanisms of action or key therapeutic factors in MSC-EVs therapy, targetedEVs could be expanded in uniform proliferative cells such as fibroblasts via gene modification technology. Therefore, with big data-based analysis of transcriptome and proteome, engineered EVs may be manufactured with desired elements. For instance, Thomas C. Roberts et al. engineered EVs to express IL6 signal transducer (IL6ST) decoy receptors to selectively inhibit the IL6 trans-signaling pathway. Treatment in the Duchenne muscular dystrophy mouse model with these IL6ST decoy receptor EVs resulted in a reduced phosphorylation of STAT3 in muscles; further functional studies verified the in vivo activity of the decoy receptor EVs as a potential therapy [204]. Similarly, CXCR4/TRAIL-enriched exosomes were successfully obtained from MSCs overexpressing both CXCR4 and TRAIL. These exosomes exerted activity as a cooperative agent with carboplatin against brain metastasis of breast cancer in vivo, improving the efficacy of chemotherapy and highlighting a novel synergistic protocol with anticancer agents to treat brain diseases [205, 206]. Moreover, in a Phase 1 clinical trial, IL-12 was engineered to express on the exosome surface using Codiak's proprietary engEx Platform. This product could enhance the dose control of IL-12 and limit systemic exposure and associated toxicity. EVs can overcome the reported limitations of parental cells on various aspects, including safety, reproducibility, and cost-effectiveness related to storage and maintenance. Engineered EVs might be novel promising therapeutics for clinical application. Furthermore, to resolve current hurdles in EVs-based therapeutics, the production of EVs should be standardized and optimized, and its underlying mechanisms need further investigation.

\section{MSC usage for pandemic diseases such as COVID-19}

Pandemic diseases like 2019 novel coronavirus disease (COVID-19) have dramatically increased the number of sickness and death worldwide. Though vaccines have been developed recently, the viruses are still rapidly mutating and expanding, and the available specific and effective treatment options are currently very limited [207]. For severe or critical COVID-19 patients requiring hospitalization, acute lung injures (ALI)/acute respiratory distress syndrome (ARDS) was the main pathologic features, characterized by immunopathological complications with cellular fibromyxoid exudates, extensive pulmonary inflammation, pulmonary edema, and hyaline membrane formation [208]. Besides, inflammation and sepsis are also the leading causes of mortality in COVID19 patients [209]. In all these cases, any treatment that could hasten recovery would be in substantial demand. MSC therapy may be one such treatment.

MSC therapeutics may be the ideal candidates for handling the broad spectrum of COVID-19 symptoms due to their multifactorial mode-of-action [210]. They can release various factors including keratinocyte growth factor, prostaglandin E2, granulocyte-macrophage colony-stimulating factor (GM-CSF), IL-6, and IL-13 to facilitate the phagocytosis and alternative activation of alveolar macrophages, alter the cytokine secretion profile of dendritic cell subsets, and decrease the release of interferon $\gamma$ from natural killer cells [211]. For example, IL-10, TGF- $\beta$, and tryptophan catabolizing enzyme indoleamine 2,3-dioxygenase secreted from them were reported to suppress the proliferation of $\mathrm{T}$ cells and change the cytokine secretion profile of $\mathrm{T}$ cell subsets [212]. Moreover, the proliferation, differentiation, and chemotactic properties of B cells were impaired by MSCs as well. Except for the immune regulatory effects, MSCs can enhance the restoration of capillary barriers, inhibit bacterial growth, and restore alveolar ATP. All these functions mentioned above might also be effective in COVID-19 infection.

COVID-19 has been the top priority of global healthcare systems since its emergence. There have been more than 160 vaccines in development and more than 60 clinical trials are ongoing, and now, only a few vaccines have been approved [213]. The representative clinical trials of MSC therapy in COVID-19 disease were listed in Table 8. But the rapid mutation of SARS-CoV-2 virus leads to challenges on the effect of the available vaccine. It is an urgent need to develop more universal and stable therapy to reverse or combat. Though no evidence has showed that coronavirus was eliminated completely after stem cell treatments, preliminary results were promising. Diseased patients were more likely to survive the infection after the treatment. The specific primed MSCs were also investigated for COVID-19 treatment [212, 214]. The results will provide a strong foundation for future scientific research and clinical applications for a variety of diseases including pandemic crisis and pulmonary complications. Hopefully, the approaches utilizing MSCs particularly the primed MSCs could be vital for the success of cell therapy in treating COVID-19.

\section{Conclusions}

Although MSCs therapies have achieved tremendous advancements over the past decades, substantial challenges remain to be overcome. The main challenges include the immunocompatibility, stability, heterogeneity, differentiation, and migratory capacity. More and more studies are focusing on the attempts to overcome these shortcomings. Although the detailed mechanism of 
Table 8 MSCs therapies for COVID-19 in clinical trials

\begin{tabular}{|c|c|c|c|c|}
\hline Study name & NCT number & Starting date & Phase & Key findings/study status \\
\hline $\begin{array}{l}\text { Mesenchymal Stem Cell Therapy for SARS-CoV-2-related Acute Respira- } \\
\text { tory Distress Syndrome }\end{array}$ & NCT04366063 & April 2020 & $2-3$ & Recruiting \\
\hline UC-MSCs in the treatment of novel coronavirus severe pneumonia & NCT04273646 & February 2020 & Not applicable & Not yet recruiting \\
\hline $\begin{array}{l}\text { A pilot clinical study on inhalation of MSCs exosomes treating severe } \\
\text { novel coronavirus pneumonia }\end{array}$ & NCT04276987 & February 2020 & 1 & Not yet recruiting \\
\hline UC-MSCs treatment for the 2019-novel coronavirus pneumonia & NCT04269525 & February 2020 & 2 & Recruiting \\
\hline Treatment with MSCs for severe corona virus disease 2019 & NCT04288102 & February 2020 & $1-2$ & Not yet recruiting \\
\hline $\begin{array}{l}\text { MSCs treatment for pneumonia patients infected with } 2019 \text { novel } \\
\text { coronavirus }\end{array}$ & NCT04252118 & January 2020 & 1 & Recruiting \\
\hline $\begin{array}{l}\text { Nest Cell }{ }^{\circledR} \text { Mesenchymal Stem Cell to Treat Patients with Severe COVID19 } \\
\text { Pneumonia }\end{array}$ & NCT04315987 & April 2020 & 1 & Not yet recruiting \\
\hline $\begin{array}{l}\text { Treatment of COVID19 Patients Using Wharton's Jelly Mesenchymal Stem } \\
\text { Cells }\end{array}$ & NCT04313322 & March 2020 & 1 & Recruiting \\
\hline $\begin{array}{l}\text { Novel Coronavirus Induced Severe Pneumonia Treated by Dental Pulp } \\
\text { Mesenchymal Stem Cells }\end{array}$ & NCT04302519 & March 2020 & Early phase 1 & Not yet recruiting \\
\hline $\begin{array}{l}\text { Safety and Efficacy Study of Allogeneic Human Dental Pulp Mesenchy- } \\
\text { mal Stem Cells to Treat Severe COVID19 Patients }\end{array}$ & NCT04336254 & April 2020 & 1 and 2 & Recruiting \\
\hline $\begin{array}{l}\text { Clinical Research of Human Mesenchymal Stem Cells in the Treatment of } \\
\text { COVID19 Pneumonia }\end{array}$ & NCT04339660 & February 2020 & 1 and 2 & Recruiting \\
\hline $\begin{array}{l}\text { Bone Marrow-Derived Mesenchymal Stem Cell Treatment for Severe } \\
\text { Patients With Coronavirus Disease } 2019 \text { (COVID19) }\end{array}$ & NCT04346368 & April 2020 & 1 and 2 & Not yet recruiting \\
\hline $\begin{array}{l}\text { Adipose Mesenchymal Cells for Abatement of SARS CoV-2 Respiratory } \\
\text { Compromise in COVID-19 Disease }\end{array}$ & NCT04352803 & April 2020 & 1 & Not yet recruiting \\
\hline $\begin{array}{l}\text { A Clinical Trial to Determine the Safety and Efficacy of Hope Biosciences } \\
\text { Autologous Mesenchymal Stem Cell Therapy (HBadMSCs) to Provide } \\
\text { Protection Against COVID19 }\end{array}$ & NCT04349631 & May 2020 & 2 & Enrolling by invitation \\
\hline $\begin{array}{l}\text { Repair of Acute Respiratory Distress Syndrome by Stromal Cell Adminis- } \\
\text { tration (REALIST) (COVID19) (REALIST) }\end{array}$ & NCT03042143 & January 2019 & 1 and 2 & Recruiting \\
\hline $\begin{array}{l}\text { Safety and Efficacy of Intravenous Wharton's Jelly-Derived Mesenchymal } \\
\text { Stem Cells in Acute Respiratory Distress Syndrome due to COVID19 }\end{array}$ & NCT04390152 & June 2020 & 1 and 2 & Not yet recruiting \\
\hline $\begin{array}{l}\text { Treatment of COVID19 Associated Pneumonia with Allogenic Pooled } \\
\text { Olfactory Mucosa-derived Mesenchymal Stem Cells }\end{array}$ & NCT04382547 & May 2020 & 1 and 2 & Not yet recruiting \\
\hline $\begin{array}{l}\text { Clinical Trial to Assess the Safety and Efficacy of Intravenous Administra- } \\
\text { tion of Allogeneic Adult Mesenchymal Stem Cells of Expanded Adipose } \\
\text { Tissue in Patients with Severe Pneumonia due to COVID19 }\end{array}$ & NCT04366323 & April 2020 & 1 and 2 & Not yet recruiting \\
\hline $\begin{array}{l}\text { Study of the Safety of Therapeutic Tx with Immunomodulatory MSC in } \\
\text { Adults with COVID19 Infection Requiring Mechanical Ventilation }\end{array}$ & NCT04397796 & June 2020 & 1 & Not yet recruiting \\
\hline $\begin{array}{l}\text { Efficacy and Safety Evaluation of Mesenchymal Stem Cells for the Treat- } \\
\text { ment of Patients with Respiratory Distress to COVID19 }\end{array}$ & NCT04390139 & May 2020 & 1 and 2 & Recruiting \\
\hline $\begin{array}{l}\text { Mesenchymal Stem Cells (MSCs) in Inflammation-Resolution Programs } \\
\text { of Coronavirus Disease } 2019 \text { (COVID19) Induced Acute Respiratory } \\
\text { Distress Syndrome }\end{array}$ & NCT04377334 & May 2020 & 2 & Not yet Recruiting \\
\hline $\begin{array}{l}\text { Efficacy and Safety Study of Allogeneic HB-adMSCs for the Treatment of } \\
\text { COVID19 }\end{array}$ & NCT04362189 & May 2020 & 3 & Not yet Recruiting \\
\hline $\begin{array}{l}\text { Clinical Trial of Allogeneic Mesenchymal Cells from Umbilical Cord Tissue } \\
\text { in Patients with COVID19 }\end{array}$ & NCT04366271 & May 2020 & 2 & Recruiting \\
\hline $\begin{array}{l}\text { A Randomized, Double-Blind, Placebo-Controlled Clinical Trial to } \\
\text { Determine the Safety and Efficacy of Hope Biosciences Allogeneic } \\
\text { Mesenchymal Stem Cell Therapy (HBadMSCs) to Provide Protection } \\
\text { Against COVID19 }\end{array}$ & NCT04348435 & April 2020 & 2 & Enrolling by invitation \\
\hline $\begin{array}{l}\text { Safety and Effectiveness of Mesenchymal Stem Cells in the Treatment of } \\
\text { Pneumonia of Coronavirus Disease } 2019\end{array}$ & NCT04371601 & March 2020 & 2 & Active not Recruiting \\
\hline Use of UC-MSCs for COVID19 Patients & NCT04355728 & April 2020 & Early Phase 1 & Recruiting \\
\hline Clinical Use of Stem Cells for the Treatment of COVID19 & NCT04392778 & April 2020 & 1 and 2 & Recruiting \\
\hline $\begin{array}{l}\text { Study of the Safety of Therapeutic Tx with Immunomodulatory MSC in } \\
\text { Adults with COVID19 Infection Requiring Mechanical Ventilation }\end{array}$ & NCT04397796 & June 2020 & 1 and 2 & Not yet Recruiting \\
\hline
\end{tabular}


Table 8 (continued)

\begin{tabular}{|c|c|c|c|c|}
\hline Study name & NCT number & Starting date & Phase & Key findings/study status \\
\hline $\begin{array}{l}\text { Efficacy and Safety Evaluation of Mesenchymal Stem Cells for the Treat- } \\
\text { ment of Patients with Respiratory Distress to COVID19 }\end{array}$ & NCT04390139 & May 2020 & 1 & Recruiting \\
\hline
\end{tabular}

MSCs immunomodulatory effects is still elusive and any attempts to improve MSCs efficacy are still lack of evidence, the preclinical studies are developing rapidly and more standardized clinical trials are wildly carried out. It might be expected that the conversion to canonically registered MSC therapies will flourish with time. The lessons from the current MSCs investigations may provide critical guidance for investigators pursuing further translational processes. With the clarification of MSCs effectors and the emergences of new technologies assisting in-depth studies, MSCs are promising to be proved as effective treatment options for a variety of devastating conditions.

\begin{abstract}
Abbreviations
Al: Artificial intelligence; ALI: Acute lung injures; ALS: Amyotrophic lateral sclerosis; ARDS: Acute respiratory distress syndrome; BMP: Bone morphogenetic protein; BDNF: Brain-derived neurotrophic factor; CD: Crohn's disease; CM: Conditioned medium; ECM: Extracellular matrix; EDA: Ectodysplasin; EVs: Extracellular vesicles; FBR: Foreign-body response; FDA: Food and Drug Administration; GDNF: Glial cell line-derived neurotrophic factor; GM-CSF: Granulocytemacrophage colony-stimulating factor; GMP: Good manufacturing practices; GVHD: Graft-versus-host disease; hBMMSC-EVs: Extracellular vesicles from human bone marrow-derived mesenchymal stromal cells; HGF: Hepatocyte growth factor; HLA: Human leukocyte antigen; hUCMSC-EVs: Extracellular vesicles from human umbilical cord-derived mesenchymal stromal cells; IDO: Indoleamine 2,3-dioxygenase; IGF: Insulin-like growth factor; IL6ST: IL6 signal transducer; MHC: Major histocompatibility complex; MI: Myocardial infarction; MIT: Massachusetts Institute of Technology; MPs: Microparticles; MS: Multiple sclerosis; MSCs: Mesenchymal stromal cells; MVs: Microvesicles; NGF: Nerve growth factor; NTFs: Neurotrophic factors; OGVHD: Ocular graft-versus-host disease; PBMCs: Peripheral blood mononuclear cells; TALEN: Transcription activator like effector nuclease; Trx1: Thioredoxin-1;VCAM1: Vascular cell adhesion molecule-1; VEGF: Vascular endothelial growth factor; ZFNs: Zinc-finger nucleases.
\end{abstract}

\section{Acknowledgements}

The authors regret that it was not possible to include many interesting studies in the field due to limited space.

\section{Authors' contributions}

$P L L, C H$, and $X D$ designed and wrote the review. TZ, ZNY, and JYW drafted the manuscript and prepared the figures. DQP helped to modify the manuscript. All authors read and approved the final manuscript.

\section{Funding}

This work was supported by the National Key R\&D Program of China (No. 2017YFE0131600), National Natural Science Foundation of China (Nos. $81870121,81700825,81671585,82070176)$, Natural Science Foundation of Guangdong Province, China (Nos. 2019B020236004, 2019B151502006), Science and Technology Planning Project of Guangdong Province, China (No. 2017B020230004), and Science and Technology Program of Guangzhou, China (Nos. 201906010076, 201803040005).

\section{Availability of data and materials}

The material supporting the conclusions of this review is included within the article.
Ethics approval and consent to participate Not applicable.

\section{Consent for publication}

Not applicable.

\section{Competing interests}

The authors declare that they have no competing interests.

\section{Author details}

${ }^{1}$ Department of Hematology, Guangdong Provincial People's Hospital, Guangdong Academy of Medical Sciences, Guangzhou 510080, People's Republic of China. ${ }^{2}$ State Key Laboratory of Ophthalmology, Zhongshan Ophthalmic Center, Sun Yat-Sen University, Guangzhou 510060, People's Republic of China. ${ }^{3}$ Department of Hepatic Surgery and Liver Transplantation Center, The Third Affiliated Hospital of Sun Yat-Sen University, Guangzhou 510630, People's Republic of China. ${ }^{4}$ Guangdong Provincial Key Laboratory of Stem Cell and Regenerative Medicine, South China Institute for Stem Cell Biology and Regenerative Medicine, Guangzhou Institutes of Biomedicine and Health, University of Chinese Academy of Sciences, Chinese Academy of Sciences, Guangzhou 510530, People's Republic of China.

Received: 14 December 2020 Accepted: 26 January 2021

Published online: 12 February 2021

\section{References}

1. Pittenger MF, Mackay AM, Beck SC, Jaiswal RK, Douglas R, Mosca JD, et al. Multilineage potential of adult human mesenchymal stem cells. Science. 1999;284(5411):143-7.

2. Midha S, Jain KG, Bhaskar N, Kaur A, Rawat S, Giri S, et al. Tissue-specific mesenchymal stem cell-dependent osteogenesis in highly porous chitosan-based bone analogs. Stem Cells Transl Med. 2020. https://doi. org/10.1002/sctm.19-0385.

3. Vaananen HK. Mesenchymal stem cells. Ann Med. 2005;37(7):469-79.

4. Ullah I, Subbarao RB, Rho GJ. Human mesenchymal stem cells_current trends and future prospective. Biosci Rep. 2015;35(2):e00191.

5. Reagan MR, Kaplan DL. Concise review: Mesenchymal stem cell tumorhoming: detection methods in disease model systems. Stem Cells. 2011:29(6):920-7.

6. Levy O, Kuai R, Siren EMJ, Bhere D, Milton Y, Nissar N, et al. Shattering barriers toward clinically meaningful MSC therapies. Sci Adv. 2020;6(30):6884.

7. Martínez-Carrasco R, Sánchez-Abarca LI, Nieto-Gómez C, Martín García E, Sánchez-Guijo F, Argüeso P, et al. Subconjunctival injection of mesenchymal stromal cells protects the cornea in an experimental model of GVHD. Ocul Surf. 2019;17(2):285-94.

8. Petrou P, GothelfY, Argov Z, Gotkine M, Levy YS, Kassis I, et al. Safety and clinical effects of mesenchymal stem cells secreting neurotrophic factor transplantation in patients with amyotrophic lateral sclerosis: results of phase 1/2 and 2a clinical trials. JAMA Neurol. 2016;73(3):337-44.

9. Zhao K, Liu Q. The clinical application of mesenchymal stromal cells in hematopoietic stem cell transplantation. J Hematol Oncol. 2016;9(1):46.

10. Park YB, Ha CW, Lee CH, Yoon YC, Park YG. Cartilage regeneration in osteoarthritic patients by a composite of allogeneic umbilical cord blood-derived mesenchymal stem cells and hyaluronate hydrogel: results from a clinical trial for safety and proof-of-concept with 7 years of extended follow-up. Stem Cells Transl Med. 2017;6(2):613-21.

11. Rubin R. Unproven but profitable: the boom in US stem cell clinics. JAMA. 2018;320(14):1421-3. 
12. Dimmeler S, Ding S, Rando TA, Trounson A. Translational strategies and challenges in regenerative medicine. Nat Med. 2014;20(8):814-21.

13. Wang S, Qu X, Zhao RC. Clinical applications of mesenchymal stem cells. J Hematol Oncol. 2012;5:19.

14. Conrad C, Niess H, Huss R, Huber S, von Luettichau I, Nelson PJ, et al. Multipotent mesenchymal stem cells acquire a lymphendothelial phenotype and enhance lymphatic regeneration in vivo. Circulation. 2009;119(2):281-9.

15. Haga H, Yan IK, Takahashi K, Wood J, Zubair A, Patel T. Tumour cellderived extracellular vesicles interact with mesenchymal stem cells to modulate the microenvironment and enhance cholangiocarcinoma growth. J Extracell Vesicles. 2015;4:24900.

16. Ankrum JA, Ong JF, Karp JM. Mesenchymal stem cells: immune evasive, not immune privileged. Nat Biotechnol. 2014;32(3):252-60.

17. Barrachina L, Remacha AR, Romero A, Vázquez FJ, Albareda J, Prades M, et al. Priming equine bone marrow-derived mesenchymal stem cells with proinflammatory cytokines: implications in immunomodulationimmunogenicity balance, cell viability, and differentiation potential. Stem Cells Dev. 2017;26(1):15-24.

18. Chan JL, Tang KC, Patel AP, Bonilla LM, Pierobon N, Ponzio NM, et al. Antigen-presenting property of mesenchymal stem cells occurs during a narrow window at low levels of interferon-gamma. Blood. 2006;107(12):4817-24.

19. Skrahin A, Ahmed RK, Ferrara G, Rane L, Poiret T, Isaikina Y, et al. Autologous mesenchymal stromal cell infusion as adjunct treatment in patients with multidrug and extensively drug-resistant tuberculosis: an open-label phase 1 safety trial. Lancet Respir Med. 2014;2(2):108-22.

20. Joswig AJ, Mitchell A, Cummings KJ, Levine GJ, Gregory CA, Smith R 3rd, et al. Repeated intra-articular injection of allogeneic mesenchymal stem cells causes an adverse response compared to autologous cells in the equine model. Stem Cell Res Ther. 2017;8(1):42.

21. Rowland AL, Xu JJ, Joswig AJ, Gregory CA, Antczak DF, Cummings KJ, et al. In vitro MSC function is related to clinical reaction in vivo. Stem Cell Res Ther. 2018;9(1):295.

22. Xia X, Chan KF, Wong GTY, Wang P, Liu L, Yeung BPM, et al. Mesenchymal stem cells promote healing of nonsteroidal anti-inflammatory drug-related peptic ulcer through paracrine actions in pigs. Sci Transl Med. 2019;11(516):eaat7455.

23. Ciuffreda MC, Malpasso G, Musarò P, Turco V, Gnecchi M. Protocols for in vitro differentiation of human mesenchymal stem cells into osteogenic, chondrogenic and adipogenic lineages. Methods Mol Biol. 2016;1416:149-58.

24. Čamernik K, Zupan J. Complete assessment of multilineage differentiation potential of human skeletal muscle-derived mesenchymal stem/ stromal cells. Methods Mol Biol. 2019;2045:131-44.

25. Haraszti RA, Didiot MC, Sapp E, Leszyk J, Shaffer SA, Rockwell HE, et al. High-resolution proteomic and lipidomic analysis of exosomes and microvesicles from different cell sources. J Extracell Vesicles. 2016;5:32570

26. Wang X, Shah FA, Vazirisani F, Johansson A, Palmquist A, Omar O, et al. Exosomes influence the behavior of human mesenchymal stem cells on titanium surfaces. Biomaterials. 2020;230:119571.

27. Jozkowiak M, Hutchings G, Jankowski M, Kulcenty K, Mozdziak P, Kempisty $B$, et al. The stemness of human ovarian granulosa cells and the role of resveratrol in the differentiation of MSCs-A review based on cellular and molecular knowledge. Cells. 2020;9(6):1418.

28. Lin GL, Hankenson KD. Integration of BMP, Wnt, and notch signaling pathways in osteoblast differentiation. J Cell Biochem. 2011;112(12):3491-501.

29. Lu GM, Rong YX, Liang ZJ, Hunag DL, Ma YF, Luo ZZ, et al. Multiomics global landscape of stemness-related gene clusters in adipose-derived mesenchymal stem cells. Stem Cell Res Ther. 2020;11(1):310,

30. Tao X, Sun MY, Chen M, Ying RC, Su WJ, Zhang J, et al. HMGB1-modified mesenchymal stem cells attenuate radiation-induced vascular injury possibly via their high motility and facilitation of endothelial differentiation. Stem Cell Res Ther. 2019:10(1):92.

31. Wang HM, Zhou Y, Yu D, Zhu HY. Klf2 contributes to the stemness and self-renewal of human bone marrow stromal cells. Cytotechnology. 2016;68(4):839-48.
32. Choi MR, In YH, Park J, Park T, Jung KH, Chai JC, et al. Genome-scale DNA methylation pattern profiling of human bone marrow mesenchymal stem cells in long-term culture. Exp Mol Med. 2012;44(8):503-12.

33. Murphy M. Delayed early embryonic lethality following disruption of the murine cyclin A2 gene. Nat Genet. 1997;15(1):83-6.

34. Baple EL, Chambers H, Cross HE, Fawcett H, Nakazawa Y, Chioza BA, et al. Hypomorphic PCNA mutation underlies a human DNA repair disorder. J Clin Invest. 2014;124(7):3137-46.

35. Toukoki C, Gryllos I. PolA1, a Putative DNA Polymerase I, Is coexpressed with PerR and contributes to peroxide stress defenses of group A streptococcus. J Bacteriol. 2013;195(4):717-25.

36. Palles C, Cazier JB, Howarth KM, Domingo E, Jones AM, Broderick P, et al. Germline mutations affecting the proofreading domains of POLE and POLD1 predispose to colorectal adenomas and carcinomas. Nat Genet. 2013;45(2):136-44.

37. Xiang J, Fang LK, Luo YX, Yang ZL, Liao Y, Cui J, et al. Levels of human replication factor $C 4$, a clamp loader, correlate with tumor progression and predict the prognosis for colorectal cancer. J Transl Med. 2014;12:320.

38. LiY, Benezra R. Identification of a human mitotic checkpoint gene: hsMAD2. Science. 1996;274(5285):246-8.

39. Al Jord A, Shihavuddin A, Servignat d'Aout R, Faucourt M, Genovesio A, Karaiskou A, et al. Calibrated mitotic oscillator drives motile ciliogenesis. Science. 2017;358(6364):803-6.

40. Gong D, Ferrell JE. The roles of cyclin A2, B1, and B2 in early and late mitotic events. Mol Biol Cell. 2010;21(18):3149-61.

41. Fenwick AL, Kliszczak M, Cooper F, Murray J, Sanchez-Pulido L, Twigg SRF, et al. Mutations in CDC45, encoding an essential component of the pre-initiation complex, cause meier-gorlin syndrome and craniosynostosis. Am J Hum Genet. 2016;99(1):125-38.

42. Aiken J, Moore JK, Bates EA. TUBA1 A mutations identified in lissencephaly patients dominantly disrupt neuronal migration and impair dynein activity. Hum Mol Genet. 2019;28(8):1227-43.

43. Morris EJ, Ji JY, Yang FJ, Di Stefano L, Herr A, Moon NS, et al. E2F1 represses beta-catenin transcription and is antagonized by both pRB and CDK8. Nature. 2008;455(7212):552-6.

44. Caldas H, Holloway MP, Hall BM, Qualman SJ, Altura RA. Survivindirected RNA interference cocktail is a potent suppressor of tumour growth in vivo. J Med Genet. 2006;43(2):119-28.

45. Wang YB, Li S, Smith K, Waldman BC, Waldman AS. Intrachromosomal recombination between highly diverged DNA sequences is enabled in human cells deficient in Bloom helicase. DNA Repair (Amst). 2016;41:73-84

46. Kim H, Wrann CD, Jedrychowski M, Vidoni S, Kitase Y, Nagano K, et al. Irisin mediates effects on bone and fat via aV integrin receptors. Cell. 2018;175(7):1756-68.

47. Pan SH, Tai CC, Lin CS, Hsu WB, Chou SF, Lai CC, et al. Epstein-Barr virus nuclear antigen 2 disrupts mitotic checkpoint and causes chromosomal instability. Carcinogenesis. 2009;30(2):366-75.

48. Ng CP, Sharif AR, Heath DE, Chow JW, Zhang CB, Chan-Park MB, et al. Enhanced ex vivo expansion of adult mesenchymal stem cells by fetal mesenchymal stem cell ECM. Biomaterials. 2014;35(13):4046-57.

49. Zhang L, Mack R, Breslin P, Zhang J. Molecular and cellular mechanisms of aging in hematopoietic stem cells and their niches. J Hematol Oncol. 2020;13(1):157.

50. Cao H, Xiao J, Reeves ME, Payne K, Chen CS, Baylink DJ, et al. Discovery of proangiogenic $C D 44+$ mesenchymal cancer stem cells in an acute myeloid leukemia patient's bone marrow. J Hematol Oncol. 2020;13(1):63.

51. Kim JH, Shin SH, LiTZ, Suh H. Influence of in vitro biomimicked stem cell "niche" for regulation of proliferation and differentiation of human bone marrow-derived mesenchymal stem cells to myocardial phenotypes: serum starvation without aid of chemical agents and prevention of spontaneous stem cell transformation enhanced by the matrix environment. J Tissue Eng Regen Med. 2016;10(1):E1-13.

52. Rodriguez R, Rubio R, Masip M, Catalina P, Nieto A, de la Cueva T, et al. Loss of p53 induces tumorigenesis in p21-deficient mesenchymal stem cells. Neoplasia. 2009;11(4):397-407.

53. McLean K, Gong Y, Choi Y, Deng N, Yang K, Bai S, et al. Human ovarian carcinoma-associated mesenchymal stem cells regulate cancer stem 
cells and tumorigenesis via altered BMP production. J Clin Invest. 2011;121(8):3206-19.

54. Direkze NC, Hodivala-Dilke K, Jeffery R, Hunt T, Poulsom R, Oukrif D, et al. Bone marrow contribution to tumor-associated myofibroblasts and fibroblasts. Cancer Res. 2004;64(23):8492-5.

55. Yoshida GJ, Azuma A, Miura Y, Orimo A. Activated fibroblast program orchestrates tumor initiation and progression; molecular mechanisms and the associated therapeutic strategies. Int J Mol Sci. 2019;20(9):2256.

56. Jeon ES, Moon HJ, Lee MJ, Song HY, Kim YM, Cho M, et al. Cancerderived lysophosphatidic acid stimulates differentiation of human mesenchymal stem cells to myofibroblast-like cells. Stem Cells. 2008;26(3):789-97.

57. Yoshida GJ. Regulation of heterogeneous cancer-associated fibroblasts: the molecular pathology of activated signaling pathways. J Exp Clin Cancer Res. 2020;39(1):112.

58. Maeda K, Enomoto A, Hara A, Asai N, Kobayashi T, Horinouchi A, et al. Identification of meflin as a potential marker for mesenchymal stromal cells. Sci Rep. 2016;6:22288.

59. Mizutani Y, Kobayashi H, lida T, Asai N, Masamune A, Hara A, et al. Meflin-positive cancer-associated fibroblasts inhibit pancreatic carcinogenesis. Cancer Res. 2019;79(20):5367-81.

60. Li X, Zeng $X, X u Y$, Wang B, Zhao Y, Lai X, et al. Mechanisms and rejuvenation strategies for aged hematopoietic stem cells. J Hematol Oncol. 2020;13(1):31

61. Gallina C, Capelôa T, Saviozzi S, Accomasso L, Catalano F, Tullio F, et al. Human mesenchymal stem cells labelled with dye-loaded amorphous silica nanoparticles: long-term biosafety, stemness preservation and traceability in the beating heart. J Nanobiotechnol. 2015;13:77.

62. Nicolay NH, Lopez Perez R, Debus J, Huber PE. Mesenchymal stem cells - a new hope for radiotherapy-induced tissue damage? Cancer Lett. 2015;366(2):133-40.

63. Fong CY, Subramanian A, Biswas A, Bongso A. Freezing of fresh Wharton's jelly from human umbilical cords yields high post-thaw mesenchymal stem cell numbers for cell-based therapies. J Cell Biochem. 2016;117(4):815-27.

64. Yin Z, Dong C, Jiang K, Xu Z, Li R, Guo K, et al. Heterogeneity of cancerassociated fibroblasts and roles in the progression, prognosis, and therapy of hepatocellular carcinoma. J Hematol Oncol. 2019;12(1):101.

65. Tallone T, Realini C, Böhmler A, Kornfeld C, Vassalli G, Moccetti T, et al. Adult human adipose tissue contains several types of multipotent cells. J Cardiovasc Transl Res. 2011;4(2):200-10.

66. Andrzejewska A, Dabrowska S, Nowak B, Walczak P, Lukomska B, Janowski M. Mesenchymal stem cells injected into carotid artery to target focal brain injury home to perivascular space. Theranostics. 2020;10(15):6615-28.

67. Ducret M, Farges JC, Pasdeloup M, Perrier-Groult E, Mueller A, MalleinGerin F, et al. Phenotypic identification of dental pulp mesenchymal stem/stromal cells subpopulations with multiparametric flow cytometry. Methods Mol Biol. 2019;1922:77-90.

68. Yang H, Gao LN, An Y, Hu CH, Jin F, Zhou J, et al. Comparison of mesenchymal stem cells derived from gingival tissue and periodontal ligament in different incubation conditions. Biomaterials. 2013:34(29):7033-47.

69. Choi YS, Park SN, Suh H. Adipose tissue engineering using mesenchymal stem cells attached to injectable PLGA spheres. Biomaterials. 2005;26(29):5855-63.

70. Holan V, Trosan P, Cejka C, Javorkova E, Zajicova A, Hermankova B, et al. A comparative study of the therapeutic potential of mesenchymal stem cells and limbal epithelial stem cells for ocular surface reconstruction. Stem Cells TransI Med. 2015;4(9):1052-63.

71. Roura S, Farré J, Soler-Botija C, Llach A, Hove-Madsen L, Cairó JJ, et al. Effect of aging on the pluripotential capacity of human CD105+ mesenchymal stem cells. Eur J Heart Fail. 2006;8(6):555-63.

72. Pogozhykh O, Pogozhykh D, Neehus AL, Hoffmann A, Blasczyk R, Müller T. Molecular and cellular characteristics of human and non-human primate multipotent stromal cells from the amnion and bone marrow during long term culture. Stem Cell Res Ther. 2015;6(1):150.

73. Sarkar D, Spencer JA, Phillips JA, Zhao W, Schafer S, Spelke DP, et al. Engineered cell homing. Blood. 2011;118(25):e184-191.
74. Won YW, Patel AN, Bull DA. Cell surface engineering to enhance mesenchymal stem cell migration toward an SDF-1 gradient. Biomaterials. 2014;35(21):5627-35.

75. Pallares V, Unzueta U, Falgas A, Sanchez-Garcia L, Serna N, Gallardo A, et al. An Auristatin nanoconjugate targeting CXCR4+ leukemic cells blocks acute myeloid leukemia dissemination. J Hematol Oncol. 2020;13(1):36.

76. Huang J, Zhang Z, Guo J, Ni A, Deb A, Zhang L, et al. Genetic modification of mesenchymal stem cells overexpressing CCR1 increases cell viability, migration, engraftment, and capillary density in the injured myocardium. Circ Res. 2010;106(11):1753-62.

77. Li H, Jiang $Y$, Jiang $X$, Guo $X$, Ning H, Li Y, et al. CCR7 guides migration of mesenchymal stem cell to secondary lymphoid organs: a novel approach to separate GvHD from GvL effect. Stem Cells. 2014;32(7):1890-903.

78. Robles JD, Liu YP, Cao J, Xiang Z, Cai Y, Manio M, et al. Immunosuppressive mechanisms of human bone marrow derived mesenchymal stromal cells in BALB/C host graft versus host disease murine models. Exp Hematol Oncol. 2015;4:13.

79. Zhang $X$, Huang W, Chen X, Lian Y, Wang J, Cai C, et al. CXCR5-overexpressing mesenchymal stromal cells exhibit enhanced homing and can decrease contact hypersensitivity. Mol Ther. 2017;25(6):1434-47.

80. Liu Z, Mikrani R, Zubair HM, Taleb A, Naveed M, Baig M, et al. Systemic and local delivery of mesenchymal stem cells for heart renovation: challenges and innovations. Eur J Pharmacol. 2020;876:173049.

81. Li L, Dong L, Zhang J, Gao F, Hui J, Yan J. Mesenchymal stem cells with downregulated Hippo signaling attenuate lung injury in mice with lipopolysaccharide-induced acute respiratory distress syndrome. Int J Mol Med. 2019;43(3):1241-52.

82. Dick AJ, Guttman MA, Raman VK, Peters DC, Pessanha BS, Hill JM, et al. Magnetic resonance fluoroscopy allows targeted delivery of mesenchymal stem cells to infarct borders in Swine. Circulation. 2003;108(23):2899-904.

83. Monsanto MM, Wang BJ, Ehrenberg ZR, Echeagaray O, White KS, Alvarez $\mathrm{R} \mathrm{Jr}$, et al. Enhancing myocardial repair with CardioClusters. Nat Commun. 2020;11(1):3955.

84. Srivastava AK, Bulte CA, Shats I, Walczak P, Bulte JW. Co-transplantation of syngeneic mesenchymal stem cells improves survival of allogeneic glial-restricted precursors in mouse brain. Exp Neurol. 2016;275 Pt 1((0-1)):154-61.

85. Neuhuber B, Swanger SA, Howard L, Mackay A, Fischer I. Effects of plating density and culture time on bone marrow stromal cell characteristics. Exp Hematol. 2008;36(9):1176-85.

86. Colter DC, Class R, DiGirolamo CM, Prockop DJ. Rapid expansion of recycling stem cells in cultures of plastic-adherent cells from human bone marrow. Proc Natl Acad Sci U S A. 2000;97(7):3213-8.

87. Zhao Q, Zhang L, Wei Y, Yu H, Zou L, Huo J, et al. Systematic comparison of hUC-MSCs at various passages reveals the variations of signatures and therapeutic effect on acute graft-versus-host disease. Stem Cell Res Ther. 2019;10(1):354.

88. Ryan AE, Lohan P, O'Flynn L, Treacy O, Chen X, Coleman C, et al. Chondrogenic differentiation increases antidonor immune response to allogeneic mesenchymal stem cell transplantation. Mol Ther. 2014;22(3):655-67.

89. Nekouian S, Sojoodi M, Nadri S. Fabrication of conductive fibrous scaffold for photoreceptor differentiation of mesenchymal stem cell. J Cell Physiol. 2019. https://doi.org/10.1002/jcp.28238.

90. Khan AA, Huat TJ, Al Mutery A, El-Serafi AT, Kacem HH, Abdallah SH, et al. Significant transcriptomic changes are associated with differentiation of bone marrow-derived mesenchymal stem cells into neural progenitor-like cells in the presence of bFGF and EGF. Cell Biosci. 2020;10:126.

91. Venkatesh K, Sen D. Mesenchymal stem cells as a source of dopaminergic neurons: a potential cell based therapy for Parkinson's disease. Curr Stem Cell Res Ther. 2017;12(4):326-47.

92. Gnecchi M, He H, Noiseux N, Liang OD, Zhang L, Morello F, et al. Evidence supporting paracrine hypothesis for Akt-modified mesenchymal stem cell-mediated cardiac protection and functional improvement. FASEB J. 2006;20(6):661-9. 
93. Dai W, Hale SL, Kloner RA. Role of a paracrine action of mesenchymal stem cells in the improvement of left ventricular function after coronary artery occlusion in rats. Regen Med. 2007;2(1):63-8.

94. Ko HR, Ahn SY, Chang YS, Hwang I, Yun T, Sung DK, et al. Human UCB-MSCs treatment upon intraventricular hemorrhage contributes to attenuate hippocampal neuron loss and circuit damage through BDNF-CREB signaling. Stem Cell Res Ther. 2018;9(1):326.

95. Whone AL, Kemp K, Sun M, Wilkins A, Scolding NJ. Human bone marrow mesenchymal stem cells protect catecholaminergic and serotonergic neuronal perikarya and transporter function from oxidative stress by the secretion of glial-derived neurotrophic factor. Brain Res. 2012;1431:86-96.

96. Silva M, Monteiro GA, Fialho AM, Bernardes N, da Silva CL. Conditioned medium from azurin-expressing human mesenchymal stromal cells demonstrates antitumor activity against breast and lung cancer cell lines. Front Cell Dev Biol. 2020;8:471.

97. Guo L, Lai P, Wang Y, Huang T, Chen X, Geng S, et al. Extracellular vesicles derived from mesenchymal stem cells prevent skin fibrosis in the CGVHD mouse model by suppressing the activation of macrophages and B cells immune response. Int Immunopharmacol. 2020;84:106541.

98. Lai P, Weng J, Guo L, Chen X, Du X. Novel insights into MSC-EVs therapy for immune diseases. Biomark Res. 2019;7:6

99. Guo L, Lai P, Wang Y, Huang T, Chen X, Luo C, et al. Extracellular vesicles from mesenchymal stem cells prevent contact hypersensitivity through the suppression of Tc1 and Th1 cells and expansion of regulatory T cells. Int Immunopharmacol. 2019;74:105663.

100. Wang W, Han Y, Jo HA, Lee J, Song YS. Non-coding RNAs shuttled via exosomes reshape the hypoxic tumor microenvironment. J Hematol Oncol. 2020;13(1):67.

101. Rostom DM, Attia N, Khalifa HM, Abou Nazel MW, El Sabaawy EA. The therapeutic potential of extracellular vesicles versus mesenchymal stem cells in liver damage. Tissue Eng Regen Med. 2020;17(4):537-52.

102. Swartzlander MD, Blakney AK, Amer LD, Hankenson KD, Kyriakides TR, Bryant SJ. Immunomodulation by mesenchymal stem cells combats the foreign body response to cell-laden synthetic hydrogels. Biomaterials. 2015;41:79-88

103. Tzouanas SN, Ekenseair AK, Kasper FK, Mikos AG. Mesenchymal stem cell and gelatin microparticle encapsulation in thermally and chemically gelling injectable hydrogels for tissue engineering. J Biomed Mater Res A. 2014;102(5):1222-30.

104. Zhang X, Yang Y, Zhang L, Lu Y, Zhang Q, Fan D, et al. Mesenchymal stromal cells as vehicles of tetravalent bispecific Tandab (CD3/CD19) for the treatment of B cell lymphoma combined with IDO pathway inhibitor D-1-methyl-tryptophan. J Hematol Oncol. 2017;10(1):56.

105. Ankrum JA, Dastidar RG, Ong JF, Levy O, Karp JM. Performanceenhanced mesenchymal stem cells via intracellular delivery of steroids. Sci Rep. 2014;4:4645

106. Luo L, Tang J, Nishi K, Yan C, Dinh PU, Cores J, et al. Fabrication of synthetic mesenchymal stem cells for the treatment of acute myocardial infarction in mice. Circ Res. 2017;120(11):1768-75.

107. Valles G, Bensiamar F, Crespo L, Arruebo M, Vilaboa N, Saldana L. Topographical cues regulate the crosstalk between MSCs and macrophages. Biomaterials. 2015;37:124-33.

108. Stucky EC, Schloss RS, Yarmush ML, Shreiber DI. Alginate microencapsulation of mesenchymal stromal cells enhances modulation of the neuro-inflammatory response. Cytotherapy. 2015;17(10):1353-64.

109. Follin B, Juhl M, Cohen S, Pedersen AE, Gad M, Kastrup J, et al. Human adipose-derived stromal cells in a clinically applicable injectable alginate hydrogel: phenotypic and immunomodulatory evaluation. Cytotherapy. 2015;17(8):1104-18.

110. Li LM, Han M, Jiang XC, Yin XZ, Chen F, Zhang TY, et al. Peptidetethered hydrogel scaffold promotes recovery from spinal cord transection via synergism with mesenchymal stem cells. ACS Appl Mater Interfaces. 2017;9(4):3330-42.

111. Murphy KC, Whitehead J, Zhou D, Ho SS, Leach JK. Engineering fibrin hydrogels to promote the wound healing potential of mesenchymal stem cell spheroids. Acta Biomater. 2017;64:176-86.

112. Su N, Gao PL, Wang K, Wang JY, Zhong Y, Luo Y. Fibrous scaffolds potentiate the paracrine function of mesenchymal stem cells: a new dimension in cell-material interaction. Biomaterials. 2017;141:74-85.
113. Wan S, Fu X, Ji Y, Li M, Shi X, Wang Y. FAK- and YAP/TAZ dependent mechanotransduction pathways are required for enhanced immunomodulatory properties of adipose-derived mesenchymal stem cells induced by aligned fibrous scaffolds. Biomaterials. 2018;171:107-17.

114. Olivares-Navarrete R, Hyzy SL, Slosar PJ, Schneider JM, Schwartz Z, Boyan BD. Implant materials generate different peri-implant inflammatory factors: poly-ether-ether-ketone promotes fibrosis and microtextured titanium promotes osteogenic factors. Spine (Phila Pa 1976). 2015;40(6):399-404

115. Zhu Y, Zhang K, Zhao R, Ye X, Chen X, Xiao Z, et al. Bone regeneration with micro/nano hybrid-structured biphasic calcium phosphate bioceramics at segmental bone defect and the induced immunoregulation of MSCs. Biomaterials. 2017;147:133-44.

116. Roger Y, Schack LM, Koroleva A, Noack S, Kurselis K, Krettek C, et al. Grid-like surface structures in thermoplastic polyurethane induce anti-inflammatory and anti-fibrotic processes in bone marrow-derived mesenchymal stem cells. Colloids Surf B Biointerfaces. 2016;148:104-15.

117. Gomez-Aristizabal A, Kim KP, Viswanathan S. A systematic study of the effect of different molecular weights of hyaluronic acid on mesenchymal stromal cell-mediated immunomodulation. PLOS ONE. 2016;11(1):e0147868.

118. Yuan T, Li K, Guo L, Fan H, Zhang X. Modulation of immunological properties of allogeneic mesenchymal stem cells by collagen scaffolds in cartilage tissue engineering. J Biomed Mater Res A. 2011;98(3):332-41.

119. Yang $Y$, Zhang $X$, Lin F, Xiong M, Fan D, Yuan X, et al. Bispecific CD3-HAC carried by E1A-engineered mesenchymal stromal cells against metastatic breast cancer by blocking PD-L1 and activating T cells. J Hematol Oncol. 2019;12(1):46.

120. Suresh SC, Selvaraju V, Thirunavukkarasu M, Goldman JW, Husain A, Alexander Palesty J, et al. Thioredoxin-1 (Trx1) engineered mesenchymal stem cell therapy increased pro-angiogenic factors, reduced fibrosis and improved heart function in the infarcted rat myocardium. Int J Cardiol. 2015;201:517-28.

121. Gao $P$, Ding $Q$, Wu Z, Jiang H, Fang Z. Therapeutic potential of human mesenchymal stem cells producing IL-12 in a mouse xenograft model of renal cell carcinoma. Cancer Lett. 2010;290(2):157-66.

122. Han J, Zhao J, Xu J, Wen Y. Mesenchymal stem cells genetically modified by lentivirus-mediated interleukin-12 inhibit malignant ascites in mice. Exp Ther Med. 2014;8(4):1330-4

123. Relation T, Yi T, Guess AJ, La Perle K, Otsuru S, Hasgur S, et al. Intratumoral delivery of interferongamma-secreting mesenchymal stromal cells repolarizes tumor-associated macrophages and suppresses neuroblastoma proliferation in vivo. Stem Cells. 2018;36(6):915-24.

124. Seo SH, Kim KS, Park SH, Suh YS, Kim SJ, Jeun SS, et al. The effects of mesenchymal stem cells injected via different routes on modified IL12-mediated antitumor activity. Gene Ther. 2011;18(5):488-95.

125. Cheng S, Nethi SK, Rathi S, Layek B, Prabha S. Engineered mesenchymal stem cells for targeting solid tumors: therapeutic potential beyond regenerative therapy. J Pharmacol Exp Ther. 2019;370(2):231-41.

126. Mingozzi F, High KA. Immune responses to AAV vectors: overcoming barriers to successful gene therapy. Blood. 2013;122(1):23-36.

127. Wang J, Liu X, Qiu Y, Shi Y, Cai J, Wang B, et al. Cell adhesion-mediated mitochondria transfer contributes to mesenchymal stem cell-induced chemoresistance on T cell acute lymphoblastic leukemia cells. J Hematol Oncol. 2018;11(1):11.

128. Zhao QG, Gregory CA, Lee RH, Reger RL, Qin LZ, Hai B, et al. MSCs derived from iPSCs with a modified protocol are tumor-tropic but have much less potential to promote tumors than bone marrow MSCs. Proc Natl Acad Sci U S A. 2015;112(2):530-5.

129. Gerace D, Martiniello-Wilks R, Nassif NT, Lal S, Steptoe R, Simpson AM. CRISPR-targeted genome editing of mesenchymal stem cell-derived therapies for type 1 diabetes: a path to clinical success? Stem Cell Res Ther. 2017;8(1):62.

130. Faulkner J, Jiang P, Farris D, Walker R, Dai Z. CRISPR/CAS9-mediated knockout of Abi1 inhibits p185(Bcr-Abl)-induced leukemogenesis and signal transduction to ERK and PI3K/Akt pathways. J Hematol Oncol. 2020;13(1):34

131. Golchin A, Shams F, Karami F. Advancing mesenchymal stem cell therapy with CRISPR/Cas9 for clinical trial studies. Adv Exp Med Biol. 2020;1247:89-100. 
132. Miwa H, Era T. Tracing the destiny of mesenchymal stem cells from embryo to adult bone marrow and white adipose tissue via Pdgfralpha expression. Development. 2018;145(2):dev155879.

133. von Einem JC, Guenther C, Volk HD, Grutz G, Hirsch D, Salat C, et al. Treatment of advanced gastrointestinal cancer with genetically modified autologous mesenchymal stem cells: results from the phase 1/2 TREAT-ME-1 trial. Int J Cancer. 2019;145(6):1538-46.

134. Lee S, Kim OJ, Lee KO, Jung H, Oh SH, Kim NK. Enhancing the therapeutic potential of CCL2-overexpressing mesenchymal stem cells in acute stroke. Int J Mol Sci. 2020;21(20):7795.

135. Guo XR, Hu QY, Yuan YH, Tang XJ, Yang ZS, Zou DD, et al. PTEN-mRNA engineered mesenchymal stem cell-mediated cytotoxic effects on U251 glioma cells. Oncol Lett. 2016;11(4):2733-40.

136. Hu X, Li L, Yu X, Zhang R, Yan S, Zeng Z, et al. CRISPR/Cas9-mediated reversibly immortalized mouse bone marrow stromal stem cells (BMSCs) retain multipotent features of mesenchymal stem cells (MSCs). Oncotarget. 2017;8(67):111847-65.

137. Sun S, Xiao J, Huo J, Geng Z, Ma K, Sun X, et al. Targeting ectodysplasin promotor by CRISPR/dCas9-effector effectively induces the reprogramming of human bone marrow-derived mesenchymal stem cells into sweat gland-like cells. Stem Cell Res Ther. 2018;9(1):8.

138. Meng X, Zheng M, Yu M, Bai W, Zuo L, Bu X, et al. Transplantation of CRISPRa system engineered IL 10-overexpressing bone marrowderived mesenchymal stem cells for the treatment of myocardial infarction in diabetic mice. J Biol Eng. 2019;13:49.

139. Su DN, Wu SP, Xu SZ. Mesenchymal stem cell-based Smad7 gene therapy for experimental liver cirrhosis. Stem Cell Res Ther. 2020;11(1):395.

140. Li SJ, Luo Y, Zhang LM, Yang W, Zhang GG. Targeted introduction and effective expression of hFIX at the AAVS1 locus in mesenchymal stem cells. Mol Med Rep. 2017;15(3):1313-8.

141. Lee $M H, W u X$, Zhu Y. RNA-binding protein PUM2 regulates mesenchymal stem cell fate via repression of JAK2 and RUNX2 mRNAs. J Cell Physiol. 2020;235(4):3874-85.

142. Yin $X, H u L$, Zhang $Y$, Zhu C, Cheng H, Xie X, et al. PDGFB-expressing mesenchymal stem cells improve human hematopoietic stem cell engraftment in immunodeficient mice. Bone Marrow Transplant. 2020;55(6):1029-40.

143. Marina RJ, Brannan KW, Dong KD, Yee BA, Yeo GW. Evaluation of engineered CRISPR-Cas-mediated systems for site-specific RNA editing. Cell Rep. 2020;33(5):108350.

144. Carvalho JL, Braga VB, Melo MB, Campos AC, Oliveira MS, Gomes DA, et al. Priming mesenchymal stem cells boosts stem cell therapy to treat myocardial infarction. J Cell Mol Med. 2013;17(5):617-25.

145. Noronha NC, Mizukami A, Caliari-Oliveira C, Cominal JG, Rocha $J$ LM, Covas DT, et al. Priming approaches to improve the efficacy of mesenchymal stromal cell-based therapies. Stem Cell Res Ther. 2019;10(1):131.

146. Kim DS, Jang IK, Lee MW, Ko YJ, Lee DH, Lee JW, et al. Enhanced immunosuppressive properties of human mesenchymal stem cells primed by interferon-gamma. EBioMedicine. 2018;28:261-73.

147. Mead B, Chamling X, Zack DJ, Ahmed Z, Tomarev S. TNFalpha-mediated priming of mesenchymal stem cells enhances their neuroprotective effect on retinal ganglion cells. Invest Ophthalmol Vis Sci. 2020;61(2):6.

148. Chinnadurai R, Copland IB, Patel SR, Galipeau J. IDO-independent suppression of T cell effector function by IFN-gamma-licensed human mesenchymal stromal cells. J Immunol. 2014;192(4):1491-501.

149. Rovira Gonzalez YI, Lynch PJ, Thompson EE, Stultz BG, Hursh DA. In vitro cytokine licensing induces persistent permissive chromatin at the Indoleamine 2,3-dioxygenase promoter. Cytotherapy. 2016;18(9):1114-28.

150. Takeshita K, Motoike S, Kajiya M, Komatsu N, Takewaki M, Ouhara K, et al. Xenotransplantation of interferon-gamma-pretreated clumps of a human mesenchymal stem cell/extracellular matrix complex induces mouse calvarial bone regeneration. Stem Cell Res Ther. 2017;8(1):101.

151. Jo H, Eom YW, Kim HS, Park HJ, Kim HM, Cho MY. Regulatory dendritic cells induced by mesenchymal stem cells ameliorate dextran sodium sulfate-induced chronic colitis in mice. Gut Liver. 2018;12(6):664-73.

152. Hu CD, Kosaka Y, Marcus P, Rashedi I, Keating A. Differential immunomodulatory effects of human bone marrow-derived mesenchymal stromal cells on natural killer cells. Stem Cells Dev. 2019;28(14):933-43.
153. Ma ZJ, Wang YH, Li ZG, Wang Y, Li BY, Kang HY, et al. Immunosuppressive effect of exosomes from mesenchymal stromal cells in defined medium on experimental colitis. Int J Stem Cells. 2019;12(3):440-8.

154. Lin T, Pajarinen J, Nabeshima A, Lu L, Nathan K, Jamsen E, et al. Preconditioning of murine mesenchymal stem cells synergistically enhanced immunomodulation and osteogenesis. Stem Cell Res Ther. 2017;8(1):277.

155. Sivanathan KN, Rojas-Canales DM, Hope CM, Krishnan R, Carroll RP, Gronthos S, et al. Interleukin-17A-induced human mesenchymal stem cells are superior modulators of immunological function. Stem Cells. 2015;33(9):2850-63.

156. Mathew SA, Chandravanshi B, Bhonde R. Hypoxia primed placental mesenchymal stem cells for wound healing. Life Sci. 2017;182:85-92.

157. Li B, Li C, Zhu M, Zhang Y, Du J, Xu Y, et al. Hypoxia-induced mesenchymal stromal cells exhibit an enhanced therapeutic effect on radiation-induced lung injury in mice due to an increased proliferation potential and enhanced antioxidant ability. Cell Physiol Biochem. 2017:44(4):1295-310.

158. Lee JH, Yoon YM, Lee SH. Hypoxic preconditioning promotes the bioactivities of mesenchymal stem cells via the HIF-1alpha-GRP78-Akt axis. Int J Mol Sci. 2017;18(6):1320.

159. Lan YW, Choo KB, Chen CM, Hung TH, Chen YB, Hsieh CH, et al. Hypoxiapreconditioned mesenchymal stem cells attenuate bleomycin-induced pulmonary fibrosis. Stem Cell Res Ther. 2015;6(1):97.

160. Bader AM, Klose K, Bieback K, Korinth D, Schneider M, Seifert M, et al. Hypoxic preconditioning increases survival and pro-angiogenic capacity of human cord blood mesenchymal stromal cells in vitro. PLOS ONE. 2015;10(9):e0138477.

161. Beegle J, Lakatos K, Kalomoiris S, Stewart H, Isseroff RR, Nolta JA, et al. Hypoxic preconditioning of mesenchymal stromal cells induces metabolic changes, enhances survival, and promotes cell retention in vivo. Stem Cells. 2015;33(6):1818-28.

162. Chen $X$, Zhang F, He X, Xu Y, Yang Z, Chen L, et al. Chondrogenic differentiation of umbilical cord-derived mesenchymal stem cells in type I collagen-hydrogel for cartilage engineering. Injury. 2013;44(4):540-9.

163. Breyner NM, Hell RC, Carvalho LR, Machado CB, Peixoto Filho IN, Valerio $P$, et al. Effect of a three-dimensional chitosan porous scaffold on the differentiation of mesenchymal stem cells into chondrocytes. Cells Tissues Organs. 2010;191(2):119-28.

164. Meng Q, Man Z, Dai L, Huang H, Zhang X, Hu X, et al. A composite scaffold of MSC affinity peptide-modified demineralized bone matrix particles and chitosan hydrogel for cartilage regeneration. Sci Rep. 2015;5:17802.

165. You Y, Kobayashi K, Colak B, Luo P, Cozens E, Fields L, et al. Engineered cell-degradable poly(2-alkyl-2-oxazoline) hydrogel for epicardial placement of mesenchymal stem cells for myocardial repair. Biomaterials. 2020. https://doi.org/10.1016/j.biomaterials.2020.120356.

166. Chen S, Shi J, Zhang M, Chen Y, Wang X, Zhang L, et al. Mesenchymal stem cell-laden anti-inflammatory hydrogel enhances diabetic wound healing. Sci Rep. 2015;5:18104

167. Tsai TL, Manner PA, Li WJ. Regulation of mesenchymal stem cell chondrogenesis by glucose through protein kinase C/transforming growth factor signaling. Osteoarthritis Cartilage. 2013;21(2):368-76.

168. Khan M, Ali F, Mohsin S, Akhtar S, Mehmood A, Choudhery MS, et al. Preconditioning diabetic mesenchymal stem cells with myogenic medium increases their ability to repair diabetic heart. Stem Cell Res Ther. 2013:4(3):58.

169. Hildebrandt $\mathrm{C}$, Buth $\mathrm{H}$, Thielecke $\mathrm{H}$. A scaffold-free in vitro model for osteogenesis of human mesenchymal stem cells. Tissue Cell. 2011:43(2):91-100.

170. Bartosh TJ, Ylostalo JH, Mohammadipoor A, Bazhanov N, Coble K, Claypool K, et al. Aggregation of human mesenchymal stromal cells (MSCs) into 3D spheroids enhances their antiinflammatory properties. Proc Natl Acad Sci U S A. 2010;107(31):13724-9.

171. Muttigi MS, Kim BJ, Kumar H, Park S, Choi UY, Han I, et al. Efficacy of matrilin-3-primed adipose-derived mesenchymal stem cell spheroids in a rabbit model of disc degeneration. Stem Cell Res Ther. 2020;11(1):363.

172. Bhang SH, Lee S, Shin JY, Lee TJ, Kim BS. Transplantation of cord blood mesenchymal stem cells as spheroids enhances vascularization. Tissue Eng Part A. 2012;18(19-20):2138-47. 
173. Gothelf Y, Abramov N, Harel A, Offen D. Safety of repeated transplantations of neurotrophic factors-secreting human mesenchymal stromal stem cells. Clin Transl Med. 2014;3:21.

174. Berry JD, Cudkowicz ME, Windebank AJ, Staff NP, Owegi M, Nicholson K, et al. NurOwn, phase 2, randomized, clinical trial in patients with ALS: safety, clinical, and biomarker results. Neurology. 2019:93(24):e2294-305.

175. Guess AJ, Daneault B, Wang R, Bradbury H, La Perle KMD, Fitch J, et al. Safety profile of good manufacturing practice manufactured interferon gamma-primed mesenchymal stem/stromal cells for clinical trials. Stem Cells Transl Med. 2017:6(10):1868-79.

176. de Godoy MA, Saraiva LM, de Carvalho LRP, Vasconcelos-Dos-Santos A Beiral HJV, Ramos AB, et al. Mesenchymal stem cells and cell-derived extracellular vesicles protect hippocampal neurons from oxidative stress and synapse damage induced by amyloid-beta oligomers. J Biol Chem. 2018;293(6):1957-75.

177. Wang JH, Liu XL, Sun JM, Yang JH, Xu DH, Yan SS. Role of mesenchymal stem cell derived extracellular vesicles in autoimmunity: a systematic review. World J Stem Cells. 2020;12(8):879-96.

178. Wang C, Borger V, Sardari M, Murke F, Skuljec J, Pul R, et al. Mesenchymal stromal cell-derived small extracellular vesicles induce ischemic neuroprotection by modulating leukocytes and specifically neutrophils. Stroke. 2020;51(6):1825-34.

179. Lai P, Chen X, Guo L, Wang Y, Liu X, Liu Y, et al. A potent immunomodulatory role of exosomes derived from mesenchymal stromal cells in preventing cGVHD. J Hematol Oncol. 2018;11(1):135.

180. Dreyer GJ, Groeneweg KE, Heidt S, Roelen DL, van Pel M, Roelofs H, et al. Human leukocyte antigen selected allogeneic mesenchymal stromal cell therapy in renal transplantation: the Neptune study, a phase I single-center study. Am J Transplant. 2020;20(10):2905-15.

181. McCradden MD, Stephenson EA, Anderson JA. Clinical research underlies ethical integration of healthcare artificial intelligence. Nat Med. 2020;26(9):1325-6.

182. Mak KK, Pichika MR. Artificial intelligence in drug development: present status and future prospects. Drug Discov Today. 2019;24(3):773-80.

183. Schneider P, Walters WP, Plowright AT, Sieroka N, Listgarten J, Goodnow RA Jr, et al. Rethinking drug design in the artificial intelligence era. Nat Rev Drug Discov. 2020;19(5):353-64.

184. Alberto AVP, da Silva Ferreira NC, Soares RF, Alves LA. Molecular modeling applied to the discovery of new lead compounds for $\mathrm{P} 2$ receptors based on natural sources. Front Pharmacol. 2020;11:01221.

185. Piazza I, Beaton N, Bruderer R, Knobloch T, Barbisan C, Chandat L, et al. A machine learning-based chemoproteomic approach to identify drug targets and binding sites in complex proteomes. Nat Commun. 2020;11(1):4200.

186. Adeshina YO, Deeds EJ, Karanicolas J. Machine learning classification can reduce false positives in structure-based virtual screening. Proc Natl Acad Sci U S A. 2020;117(31):18477-88.

187. Paul D, Sanap G, Shenoy S, Kalyane D, Kalia K, Tekade RK. Artificial intelligence in drug discovery and development. Drug Discov Today. 2020;26(1):80-93.

188. Bedard AC, Adamo A, Aroh KC, Russell MG, Bedermann AA, Torosian J, et al. Reconfigurable system for automated optimization of diverse chemical reactions. Science. 2018;361(6408):1220-5.

189. Norgeot B, Quer G, Beaulieu-Jones BK, Torkamani A, Dias R, Gianfrancesco $M$, et al. Minimum information about clinical artificial intelligence modeling: the MI-CLAIM checklist. Nat Med. 2020;26(9):1320-4.

190. Gonem S, Janssens W, Das N, Topalovic M. Applications of artificia intelligence and machine learning in respiratory medicine. Thorax. 2020;75(8):695-701

191. Ranganath SH, Levy O, Inamdar MS, Karp JM. Harnessing the mesenchymal stem cell secretome for the treatment of cardiovascular disease. Cell Stem Cell. 2012;10(3):244-58.

192. Santamaria G, Brandi E, Vitola P, Grandi F, Ferrara G, Pischiutta F, et al. Intranasal delivery of mesenchymal stem cell secretome repairs the brain of Alzheimer's mice. Cell Death Differ. 2021;28(1):203-18.

193. Sajeesh S, Broekelman T, Mecham RP, Ramamurthi A. Stem cell derived extracellular vesicles for vascular elastic matrix regenerative repair. Acta Biomater. 2020;113:267-78.
194. Qiu G, Zheng G, Ge M, Wang J, Huang R, Shu Q, et al. Mesenchymal stem cell-derived extracellular vesicles affect disease outcomes via transfer of microRNAs. Stem Cell Res Ther. 2018:9(1):320.

195. Jeppesen DK, Fenix AM, Franklin JL, Higginbotham JN, Zhang Q, Zimmerman LJ, et al. Reassessment of exosome composition. Cell. 2019;177(2):428-45.

196. Kalluri R, LeBleu VS. The biology, function, and biomedical applications of exosomes. Science. 2020;367(6478):eaau6977.

197. Pluchino S, Smith JA. Explicating exosomes: reclassifying the rising stars of intercellular communication. Cell. 2019;177(2):225-7.

198. Poggio M, Hu T, Pai CC, Chu B, Belair CD, Chang A, et al. Suppression of Exosomal PD-L1 induces systemic anti-tumor immunity and memory. Cell. 2019;177(2):414-27.

199. Doyle LM, Wang MZ. Overview of extracellular vesicles, their origin, composition, purpose, and methods for exosome isolation and analysis. Cells. 2019;8(7):727.

200. Yin K, Wang S, Zhao RC. Exosomes from mesenchymal stem/stromal cells: a new therapeutic paradigm. Biomark Res. 2019;7:8.

201. Mendt M, Kamerkar S, Sugimoto H, McAndrews KM, Wu CC, Gagea M, et al. Generation and testing of clinical-grade exosomes for pancreatic cancer. JCI Insight. 2018;3(8):e99263.

202. Roberts-Dalton HD, Cocks A, Falcon-Perez JM, Sayers EJ, Webber JP, Watson $\mathrm{P}$, et al. Fluorescence labelling of extracellular vesicles using a novel thiol-based strategy for quantitative analysis of cellular delivery and intracellular traffic. Nanoscale. 2017:9(36):13693-706.

203. Saleh AF, Lazaro-lbanez E, Forsgard MA, Shatnyeva O, Osteikoetxea X, Karlsson $F$, et al. Extracellular vesicles induce minimal hepatotoxicity and immunogenicity. Nanoscale. 2019;11(14):6990-7001.

204. Conceicao M, Forcina L, Wiklander OPB, Gupta D, Nordin JZ, Vrellaku $B$, et al. Engineered extracellular vesicle decoy receptor-mediated modulation of the IL6 trans-signalling pathway in muscle. Biomaterials. 2021;266:120435

205. Liu M, Hu Y, Chen G. The antitumor effect of gene-engineered exosomes in the treatment of brain metastasis of breast cancer. Front Oncol. 2020;10:1453.

206. Tian X, Shen H, Li Z, Wang T, Wang S. Tumor-derived exosomes, myeloid-derived suppressor cells, and tumor microenvironment. J Hematol Oncol. 2019;12(1):84.

207. Stebbing J, Phelan A, Griffin I, Tucker C, Oechsle O, Smith D, et al. COVID-19: combining antiviral and anti-inflammatory treatments. Lancet Infect Dis. 2020;20(4):400-2.

208. Carlet J, Payen D, Opal SM. Steroids for sepsis and ARDS: this eternal controversy remains with COVID-19. Lancet. 2020;396(10259):e61-62.

209. Jiang L, Tang K, Levin M, Irfan O, Morris SK, Wilson K, et al. COVID-19 and multisystem inflammatory syndrome in children and adolescents. Lancet Infect Dis. 2020;20(11):e276-88.

210. Moll G, Drzeniek N, Kamhieh-Milz J, Geissler S, Volk HD, Reinke P. MSC therapies for COVID-19: importance of patient coagulopathy, thromboprophylaxis, cell product quality and mode of delivery for treatment safety and efficacy. Front Immunol. 2020;11:1091.

211. Jayaramayya K, Mahalaxmi I, Subramaniam MD, Raj N, Dayem AA, Lim KM, et al. Immunomodulatory effect of mesenchymal stem cells and mesenchymal stem-cell-derived exosomes for COVID-19 treatment. BMB Rep. 2020;53(8):400-12.

212. Leng Z, Zhu R, Hou W, Feng Y, Yang Y, Han Q, et al. Transplantation of ACE2(-) mesenchymal stem cells improves the outcome of patients with COVID-19 pneumonia. Aging Dis. 2020;11(2):216-28.

213. Haynes BF, Corey L, Fernandes P, Gilbert PB, Hotez PJ, Rao S, et al. Prospects for a safe COVID-19 vaccine. Sci Transl Med. 2020;12(568):eabe0948.

214. Shetty AK. Mesenchymal stem cell infusion shows promise for combating coronavirus (COVID-19)-induced pneumonia. Aging Dis. 2020;11(2):462-4.

\section{Publisher's Note}

Springer Nature remains neutral with regard to jurisdictional claims in published maps and institutional affiliations. 